\title{
RELAÇÕES DE GÊNERO ENTRE ALUNOS E ALUNAS EM UMA INSTITUIÇÃO DE EDUCAÇÃO TECNOLÓGICA BRASILEIRA
}

\author{
Gender Relations among Female and Male \\ Studentes at a Brazilian Institution of \\ Technological Education
}

Marília Gomes de Carvalho*

Samara Feitosa**

Valter Cardoso da Silva***

\section{Resumo}

Este artigo apresenta os resultados de pesquisa desenvolvida pelo Grupo de Estudos e Pesquisas sobre Relações de Gênero e Tecnologia (GeTec), do Programa de Pós-Graduação em Tecnologia (PPGTE) da Universidade Tecnológica Federal do Paraná (UTFPR), com o objetivo de investigar as relações de gênero entre os estudantes de cursos da área tecnológica. Estes cursos possuem em sua maioria estudantes do sexo masculino e embora haja uma tendência a um aumento no número de estudantes mulheres, sua participação nesta área da formação universitária ainda é insignificante. A partir de estudos etnometodológicos buscou-se apreender como estes

* Mestre em Ciências Sociais (Antropologia), pela PUCSP, doutora em Antropologia Social pela USP e pós-doutora em Relações Interculturais pela Université de Technologie de Compiègne - França. Coordenadora do Grupo de Estudos e Pesquisas sobre Relações de Gênero e Tecnologia - GeTec/ PPGTE e professora do Programa de Pós-Graduação em Tecnologia - PPGTE, da UTFPR. (mariliagdecarvalho@gmail.com)

** Mestre em Tecnologia pelo Programa de Pós-Graduação em Tecnologia (PPGTE), da Universidade Tecnológica Federal do Paraná (UTFPR). Professora da Rede Pública do Estado do Paraná. (samarahistoria@yahoo.com.br)

*** Mestre em Tecnologia pelo Programa de Pós-Graduação em Tecnologia (PPGTE), da Universidade Tecnológica Federal do Paraná (UTFPR). Professor da Rede Pública do Estado do Paraná.

(prof-valter@hotmail.com) 
estudantes percebem as relações de gênero no curso e na profissão que escolheram. A análise destas representações revela que a igualdade de competência não implica em igualdade de oportunidades no mercado de trabalho. Os rapazes se consideram mais competentes para o trabalho técnico, devido a suas características de personalidade como a objetividade e assertividade, vistas por eles como essenciais para o sucesso profissional na área. As alunas acreditam que o maior prestígio e sucesso masculino no mercado está relacionado a condições históricas que marcaram os papéis de gênero na sociedade e que, apesar de estar em transformação, ainda não se refletiram neste campo. Portanto as representações sobre o tema oscilam entre manifestações tradicionais - marcadas por relações de poder desiguais - e as transformações que estão ocorrendo em direção à igualdade entre homens e mulheres. Este processo de mudança é acompanhado por ambigüidades que permeiam o discurso dos informantes, pois suas opiniões dificilmente são unânimes e raramente sem contradições.

Palavras-chave: tecnologia, educação, gênero.

\section{Abstract}

This article presents the results of the research developed by Gender and Technology Relations Research and Study Group (GeTec) from the Parana Technological Federal University (UTFPR), Post Graduate Program in Technology (PPGTE), aiming to investigate the gender relation amongst students of the technological area. These courses in its majority consist of male students, though there are an increasing number of women, still their numbers are yet considered insignificant. Basing concepts on ethnic-methodological studies, students show the gender relation within the course and occupation chosen. The analysis of these representations reveals that equity of competency is not related to the market acceptance and opportunities for them. Men tend to consider themselves more qualified for a technical work, due to personal characteristics, such as objectivity and assertiveness, seen by them as essential for success in this specific professional area. Women believe more regard and success given to men in the field are from 
historical conditions that kept gender roles in society and that though in transformation still do not reflect in this field. Representatives have different opinions about the subject between the traditional manifestations - demonstrated by unequal relations in power - those transformations occur towards equity for men and women. The process is accompanied by the ambiguity of each representatives speech, for their opinions are rarely unanimous and without contradiction.

Keywords: technology, education, gender.

\section{PARTE 1}

Este artigo apresenta os resultados de uma experiência de pesquisa que foi desenvolvida pelo Grupo de Estudos e Pesquisas sobre Relações de Gênero e Tecnologia (GeTec) do Programa de Pós-Graduação em Tecnologia (PPGTE), da Universidade Tecnológica Federal do Paraná (UTFPR), com o objetivo de investigar as relações de gênero entre os estudantes de cursos da área tecnológica.

Sabe-se que estes cursos possuem em sua maioria estudantes do sexo masculino. Apesar de haver uma tendência a um aumento no número de estudantes mulheres, sua participação nesta área da formação universitária ainda é insignificante. Este dado não é característica apenas do Brasil, mas se repete em vários outros países, inclusive na Alemanha ${ }^{1}$.

A fim de conhecer como os estudantes e as estudantes dos cursos tecnológicos percebem as relações de gênero no curso que estão matriculados e também na profissão que escolheram, a partir de uma perspectiva intercultural, desenvolveu-se esta pesquisa preliminar no CEFET-PR, Brasil, e outra na Fachhochschule Furtwangen, Alemanha.

1 Sobre esta questão MUNDER, I. e CARVALHO, M.G. escreveram o artigo " Mujeres y estudios técnicos, ¿conceptos compatibles? Tentativa de una comparación intercultural entre Alemania y Brasil” que foi apresentado no V Congreso Iberoaméricano “Ciencia, Tecnología y Género" entre 16 e 20 fevereiro de 2004 no México D.F. 
Antes de trazermos os resultados da investigação realizada no Brasil apresentamos uma síntese histórica da UTFPR , do PPGTE e, a seguir, do GeTec ${ }^{2}$.

A UTFPR foi fundada em 1909 com o nome de: "Escola de Aprendizes e Artífices do Paraná"3. A área de abrangência do ensino transformou-se gradativamente. No início, tratava-se de uma escola voltada ao atendimento de menores carentes, posteriormente adquiriu o perfil técnico profissionalizante (integrado ao hoje chamado ensino médio). Mais tarde surgiram os cursos de ensino superior, pós-graduação (especialização, mestrado e doutorado), cursos de extensão, aperfeiçoamento, todos da área tecnológica; além de realizar pesquisas aplicadas na área industrial.

Atualmente, a UTFPR conta com aproximadamente 15.500 alunos em todos os seus níveis de ensino, 1.330 professores e um corpo de técnicos-administrativos composto de 539 pessoas.

A UTFPR é uma autarquia vinculada ao Ministério da Educação. Tem por finalidade formar e qualificar profissionais nos vários níveis e modalidades de ensino para os diversos setores da economia, bem como realizar pesquisa e desenvolvimento tecnológico de novos processos, produtos e serviços, em estreita articulação com os setores produtivos e a sociedade, fornecendo mecanismos para a educação continuada.

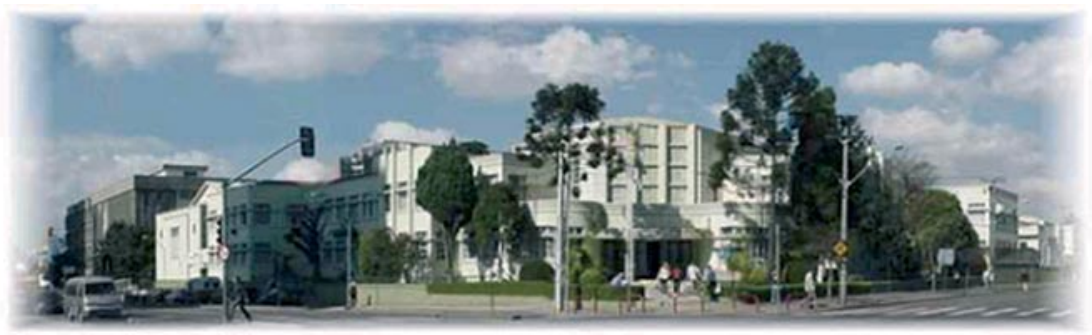

2 Agradecemos a contribuição de Cristina Tavares Rocha, pesquisadora da GeTec, na elaboração deste item do artigo.

3 No decorrer de sua história, a instituição passa por várias mudanças. Na mais recente delas, o então Centro Federal de Educação Tecnológica do Paraná (Cefet-PR) foi transformado em Universidade Tecnológica Federal do Paraná - UTFPR, sendo que além da Reitoria e de um campus em Curitiba, conta com outros dez Campi distribuídos pelo interior do Paraná (Apucarana, Campo Mourão, Cornélio Procópio, Dois Vizinhos, Francisco Beltrão, Londrina, Medianeira, Pato Branco, Ponta Grossa e Toledo). Maiores informações sobre o histórico da universidade, bem como sobre a estrutura e funcionamento dos seus cursos podem ser encontradas na pagina http://www.utfpr.edu.br/. 
A UTFPR é considerada, hoje, um centro de referência do ensino tecnológico no Sul do País, objetivando "educar com padrão de excelência”, evoluindo permanentemente e adaptando-se às mudanças, às exigências e aos constantes avanços tecnológicos da atualidade.

O Programa de Pós-Graduação em Tecnologia ${ }^{4}$, PPGTE, nível de mestrado, teve seu primeiro processo de seleção em agosto de 1995 e constitui um dos três Programas de Pós-Graduação existentes hoje na UTFPR - Campus Curitiba.

Uma das dimensões que o PPGTE se preocupa em suas pesquisas é a que trata das Dimensões Socioculturais da Tecnologia. Busca entender como a tecnologia interfere na vida em sociedade provocando mudanças nas relações sociais e culturais, e também como estas relações criam a necessidade de desenvolvimento tecnológico.

OGrupo de Estudos ePesquisas sobre Relações de Gêneroe Tecnologia (GeTec) está vinculado ao PPGTE. Graças ao caráter interdisciplinar deste Programa, os alunos ligados às suas linhas de pesquisa (a saber, Tecnologia e Trabalho, Tecnologia e Interação e Tecnologia e Desenvolvimento) podem encontrar no GeTec um espaço para o enriquecimento de seus estudos através da perspectiva de gênero.

Oficializado desde dezembro de 2000, este Grupo foi criado com os seguintes objetivos: viabilizar a discussão sobre as relações de gênero e tecnologia, através da promoção de encontros, palestras, reuniões, seminários, conferências e workshops; divulgar resultados das pesquisas e dos estudos desenvolvidos no âmbito do Grupo; estabelecer intercâmbio com outras instituições (públicas, privadas, nacionais, internacionais) interessadas na temática gênero e tecnologia; desenvolver um banco de dados constituído de estudos e pesquisas sobre gênero e tecnologia.

$\mathrm{O}$ GeTec vem se fortalecendo a cada ano, participando de eventos regionais, nacionais e internacionais; promovendo encontros e seminários; congressos, palestras; elaborando projetos de pesquisa e realizando sessão 
de projeção de filmes, com especialistas na área de Gênero e, inclusive, publicando livros e artigos dos/as seus/as pesquisadores/as ${ }^{5}$.

\section{O INÍCIO DE UMA PARCERIA ${ }^{6}$}

O Grupo de Estudos e Pesquisas sobre Relações de Gênero e Tecnologia (GeTec) do Programa de Pós-Graduação em Tecnologia (PPGTE) da Universidade Tecnológica Federal do Paraná (UTFPR) está realizando uma parceria com o TanGens-Technology and gender in applied sciences, com o intuito de realizar uma pesquisa que consiste na investigação sobre as relações e representações de gênero entre os alunos e alunas da UTFPR - Brasil e da Fachhochschule Furtwangen - Alemanha ${ }^{7}$.

$\mathrm{O}$ objetivo desta pesquisa seria o de conhecer as representações de gênero entre estudantes universitários da área tecnológica em seus respectivos países. Especificamente, pretende-se compreender como as representações sobre o que é ser homem ou ser mulher no curso e na profissão se manifestam entre os estudantes pesquisados.

A investigação foi realizada com grupos de homens e mulheres separadamente, no Brasil e na Alemanha, para que fosse possível mapear as representações de gênero que são construídas e que atravessam cada grupo e, assim, investigar como eles e elas se percebem em seu ambiente de estudo e de trabalho. Foram escolhidos cursos na UTFPR que fossem semelhantes aos cursos de FURTWANGEN para que a comparação fosse possível.

5 No site do GeTec (www.ppgte.cefetpr.br/genero) podem ser encontradas informações adicionais e mais detalhadas sobre seus objetivos, seus/as integrantes, artigos apresentados em congressos, etc..

6 As informações sobre a proposta da pesquisa em parceria entre GeTec-UTFPR e TanGensFURTWANGEN foram obtidas através da memória da reunião do GeTec ocorrida em CuritibaPR, no dia 8 de agosto de 2003, com os membros do GeTec e a professora Irmtraud Munder, da Fachhochschule Furtwangen - Alemanha.

7 Agradecemos a colaboração de Lindamir Salete Casagrande, pesquisadora do GeTec, na redação deste item do artigo. 
A pesquisa teria duas dimensões fundamentais: uma da cultura e outra das relações de gênero como mostra o modelo a seguir:

\section{BRASIL}

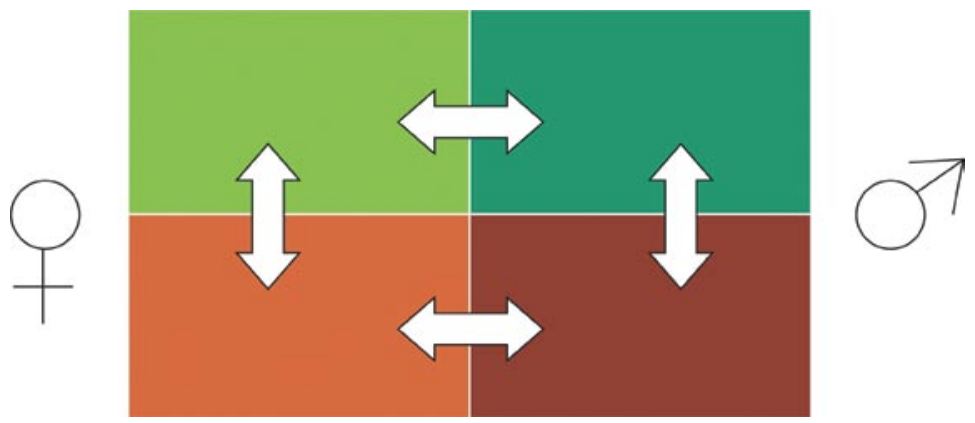

\section{ALEMANHA}

A dimensão cultural da pesquisa pode ser observada pelas setas verticais, o campo superior representa o Brasil e o inferior a Alemanha. Já as relações de gênero aparecem representadas pelas setas horizontais, sendo o campo da esquerda o lado feminino e o campo da direita o lado masculino. A comparação seria realizada em quatro níveis:

- entre mulheres brasileiras e mulheres alemãs;

- entre homens brasileiros e homens alemães;

- entre mulheres brasileiras e homens brasileiros, e

- entre mulheres alemãs e homens alemães.

O projeto teria como finalidade chegar a estas comparações através da análise das informações obtidas nas entrevistas com os alunos e alunas, das quais deveriam ser consideradas as diferenças de atitudes, as diferenças culturais, bem como os diversos valores e normas que permeiam a sociedade em que estão inseridos.

A fim de dar início aos trabalhos de investigação entre os estudantes brasileiros para uma posterior comparação com os resultados de pesquisas realizadas pelo TanGens na Alemanha, o GeTec realizou a pesquisa que será relatada a seguir. 


\section{A EXPERIÊNCIA BRASILEIRA}

Discussões teóricas foram necessárias para fundamentar a realização desta pesquisa. Conceitos como cultura, habitus, e gênero são aqui apresentados para orientar o leitor sobre a base que norteou a investigação.

A cultura é um fenômeno social construído através de relações vividas em práticas cotidianas e experiências compartilhadas. As práticas culturais são fenômenos simbólicos, cujos significados são dados pelas pessoas que os vivem e compartilham. A partir da prática social as pessoas desenvolvem representações mentais que lhes dão as referências necessárias para suas ações e atitudes (GEERTZ, 1978).

Em outras palavras, os seres humanos, a fim de atenderem as suas mais variadas necessidades sejam de ordem material, espiritual ou valorativa, criam a cultura. Esta é fruto de uma série de vivências que se constroem coletivamente através de processos que são constituídos “(...) sob a direção de padrões culturais, sistemas de significados criados historicamente em termos dos quais damos forma, ordem, objetivo e direção às nossas vidas" (GEERTZ, 1978, 64).

Pierre Bourdieu salienta que a intersubjetividade é um dos elementos constitutivos da vida social, sob a qual a sociedade é construída, reproduzida e/ou modificada. Portanto, manifestações intersubjetivas devem ser também consideradas como elementos úteis de análise sociológica. É nesta dialética constante entre a objetividade e a subjetividade que as relações sociais se constroem e se modificam, sempre a partir de representações e referências mentais, que dão significado para as ações individuais. Isto porque

(...) dirige (no duplo sentido do termo) seus pensamentos e suas práticas, tal como uma força (...) mas sem o obrigar automaticamente (...); ela guia sua ação tal qual uma necessidade lógica (...), mas sem se impor [ao agente] como uma regra ou como o implacável veredicto lógico de uma espécie de cálculo racional. Essa força superior que pode fazê-lo aceitar como inevitáveis, ou óbvios, isto é, sem deliberação nem exame, atos que seriam vistos pelos outros como impossíveis ou impensáveis, é a transcendência social que nele tomou corpo e 
funciona como amor fati, amor do destino, inclinação corporal a realizar uma identidade constituída em essência social e assim transformada em destino (BOURDIEU, 1999, p. 63).

A noção de habitus de Bourdieu reflete a interação que existe entre as manifestações da sociedade e as individuais. O habitus, portanto, é produto da sociedade e, como tal, organiza e estabelece parâmetros para a ação concreta que se realiza na medida em que é posto em prática pelos indivíduos (BOURDIEU, 1983).

Como parte da cultura, as relações e padrões de gênero estão diretamente imbricados nas práticas sociais, ao mesmo tempo em que são também referências para estas práticas. Portanto, para se compreender como são construídas as relações de gênero, as suas representações e os seus significados, é necessário considerar que elas são manifestações individuais que se pautam, no entanto na cultura, que é, por sua vez, produto da sociedade.

O gênero, então, fornece um meio de decodificar o significado e de compreender as complexas conexões entre várias formas de interação humana. Quando os/as historiadores/as buscam encontrar as maneiras pelas quais o conceito de gênero legitima e constrói as relações sociais, eles/as começam a compreender a natureza recíproca do gênero e da sociedade $e$ as formas particulares e contextualmente específicas pelas quais a política constrói o gênero e o gênero constrói a política (SCOTT, 1995, p. 89).

Para Joan Scott, as análises sobre relações de gênero permitem interpretar também outras relações sociais que evidenciam especialmente relações de poder. Gênero passa a ser uma categoria histórica que pode ser utilizada para compreender como se estabelecem as relações sociais de dominação em uma dada sociedade (SCOTT, 1995).

A dicotomia que determina características opostas para homens e mulheres traz uma série de implicações para as relações de gênero que se manifestam de maneira desigual e possibilitam a dominação masculina. Uma das áreas em que se observa claramente esta desigualdade é a tecnológica. Esta é uma área vista como um universo masculino, em que as mulheres têm 
tido pouca ou nenhuma participação. É uma representação que se formou ao longo da história da sociedade ocidental capitalista e que marcou as relações de gênero de forma a excluir as mulheres da produção e da apropriação do conhecimento tecnológico.

Sabe-se que a sociedade atual além de desigual é também culturalmente heterogênea, o que permite dizer que há vários modelos de masculinidade e feminilidade e também vários modelos de divisão sexual do trabalho. Por isso, se por um lado, a tecnologia tem sido interpretada como um universo masculino, por outro, este padrão está passando por um processo de transformação.

Este fato pode ser observado pela procura por cursos técnicos por um número cada vez maior de mulheres. Apesar de ainda serem minoria, elas estão presentes em número crescente nos cursos de tecnologia e engenharias da UTFPR, como mostra o quadro seguinte.

- QUADRO I - Alunos matriculados nos Cursos das Engenharias e Tecnologias da UTFPR, por sexo ${ }^{8}$

\begin{tabular}{|c|c|c|c|c|}
\hline Ano & $\begin{array}{c}\text { Número de } \\
\text { Homens }\end{array}$ & \% de Homens & $\begin{array}{c}\text { Número de } \\
\text { Mulheres }\end{array}$ & Total \\
1991 & 1779 & 90,7 & 9,3 & 1961 \\
1997 & 2362 & 87,2 & 12,8 & 2709 \\
2003 & 6764 & 72,5 & 27,5 & 9332 \\
\hline
\end{tabular}

Fonte: Divisão de Orçamento e Estatística da UTFPR.

Tendo em vista que as representações sobre relações de gênero são culturalmente construídas e que a sociedade em que se vive hoje é heterogênea do ponto de vista cultural, surge a indagação sobre quais seriam os modelos de relações de gênero que os jovens e as jovens que estão estudando hoje nos Cursos de Tecnologia do CEFET/PR possuem. Como eles e elas se percebem enquanto homens e/ou mulheres nos cursos que escolheram e em sua futura vida profissional?

$8 \mathrm{O}$ quadro acima apresenta todos os alunos matriculados nos cursos superiores da UTFPR nos referidos anos. Deve-se ressaltar que entre 1997 e 2003 houve a mudança nos cursos da UTFPR que deixou de ofertar os cursos Técnicos e passou a ofertar cursos de Tecnologias. 
Certamente suas representações sobre essa questão estão contidas num universo mais amplo do que as individuais, e seu desvendamento revelará como os grupos aos quais esses jovens pertencem e com os quais se identificam estão vivenciando e percebendo as relações de gênero.

\section{SOBRE O MÉTODO ${ }^{9}$}

Aproximar-se de uma realidade como a apresentada até aqui exige uma abordagem metodológica que dê conta da complexidade das situações vividas pelos sujeitos em seu cotidiano. Neste sentido consideram-se as contribuições de Karl Mannheim ${ }^{10}$ e dos teóricos da etnometodologia ${ }^{11}$ como valioso instrumento de coleta e interpretação de dados.

Com base nestes pressupostos teóricos e metodológicos e, tendo em vista os objetivos desta pesquisa, ou seja, investigar as relações de gênero entre os estudantes de cursos da área tecnológica, procurou-se então delimitar o universo a ser investigado.

\section{PROCEDIMENTOS METODOLÓGICOS 12}

Procurando atender as premissas teóricas e metodológicas da proposta da pesquisa intercultural Brasil-Alemanha sob a perspectiva de gênero, realizaram-se, como primeiro passo metodológico, reuniões e

9 Agradecemos a contribuição de Josimeire de Lima Sobreira, pesquisadora do GeTec, na redação deste item do artigo.

10 Considera-se o método documentário de interpretação adequado para este estudo porque o mesmo tem por característica a reconstrução do coletivo através da análise das falas dos próprios agentes envolvidos. Para maiores esclarecimentos sobre o tema ver WELLER, 2003.

11 Recorre-se a este método em virtude do mesmo ser o mais adequado na reconstrução das orientações coletivas dos grupos, e ainda, por contribuir para uma verificação do conhecimento do "mundo interior" de seus atores e a sua relação com os atos intencionais, pois ele facilita o acesso aos conhecimentos, não somente os reflexivos, mas também aqueles que conduzem os atores às suas ações. Os pressupostos da etnometodologia como instrumento de leitura da realidade, utilizados neste estudo tomam por base os escritos de GARFINKEL, 1967 e também de COULON, 1995.

12 Agradecemos a participação de Lindamir Salete Casagrande, Nádia T. Covolan, Sivonei Hidalgo, Josimeire de Lima Sobreira e Maria Lúcia B.Machado e Ronaldo de Oliveira Corrêa, pesquisadoras e pesquisador do GeTec, pela participação nas discussões metodológicas e colaboração na realização e transcrição das entrevistas. 
encontros com o intuito de discutir a produção teórica e metodológica que fundamentaria a pesquisa ${ }^{13}$.

Para que esta pesquisa pudesse ser realizada, era necessário que o grupo pesquisado fosse homogêneo no maior número possível de variáveis, isto é, formado por estudantes (moças e rapazes) que vivenciassem disciplinas em conjunto, que fossem do mesmo curso, pertencentes à mesma faixa etária, enfim que tivessem compartilhado várias experiências e desenvolvido uma convivência mútua. A estes pequenos grupos denominouse peer groups.

O segundo passo foi selecionar, dentre os cursos ofertados pela UTFPR e outras instituições de ensino superior, aqueles que melhor se adequassem às características necessárias para a pesquisa. De início pensou-se na área de Engenharia, especificamente o curso de Engenharia da Computação, que mais se aproximava do curso em que foi realizada parte da pesquisa na Alemanha. Entretanto, a UTFPR não ofertava tal graduação, o que levou à sua procura em outros estabelecimentos de ensino superior.

Surgiu aí nova dificuldade, pois nas duas universidades onde há este Curso (Universidade Federal do Paraná e Pontifícia Universidade Católica do Paraná), os alunos são predominantemente rapazes. Este fato impossibilitou a realização do trabalho, uma vez que não havia número suficiente de mulheres para compor um peer-group.

Voltou-se então para a busca de outros cursos da UTFPR . O curso de Tecnologia em Informática também se enquadrava no perfil procurado, porém repetia-se a mesma situação anterior: não apresentava número suficiente de alunas. Diante destes obstáculos, a opção pelos cursos do Departamento Acadêmico de Desenho Industrial (Tecnologia em Desenho de Móveis e Tecnologia em Artes Gráficas) surgiu como a mais viável, uma vez que os mesmos envolviam conhecimentos e habilidades na área da estética, da criatividade, da utilização de multimeios, dentre outros. Embora

13 Para esta discussão metodológica foi fundamental a participação de Wivian Weller, socióloga da Universidade de Brasília, que esteve em Curitiba, conduzindo o Workshop promovido pelo GeTec na UTFPR nos dias 6 e 7 de maio de 2004 sobre Método documentário de interpretação: aspectos teóricos e metodológicos. Sobre este assunto ver WELLER, W. 2003 e 2004. 
o curso de Tecnologia em Desenho de Móveis tivesse maioria feminina e o de Artes Gráficas uma maioria masculina, grande parte da grade de disciplinas é feita em conjunto, criando a interação necessária para a composição dos peer-groups. Foram escolhidas duas turmas, compostas por 27 moças e 12 rapazes no período da noite e, outra, no período da manhã, composta por 8 rapazes e 14 moças. Foram esses os cursos selecionados para a realização das entrevistas, pois são os que mais de aproximam das características do curso de Mídia Digital onde foi realizada a pesquisa em Furtwangen.

Antes de iniciar a pesquisa de campo, decidiu-se testar a metodologia. $\mathrm{O}$ quarto passo metodológico foi a realização de uma pesquisa-piloto num colégio estadual da cidade de Curitiba. Escolheu-se uma turma que possuía um número equilibrado de moças e rapazes, que já estavam estudando juntos há tempo suficiente para a constituição de um peer-group.

Concluída a experiência-piloto, realizou-se uma reunião de avaliação com os pesquisadores. Considerou-se que a compreensão das características pessoais de cada participante tornaria mais fácil a interpretação dos resultados das entrevistas. Desenvolveu-se então uma ficha de caracterização a ser preenchida pelos entrevistados na qual constariam dados pessoais como idade, sexo, raça e etnia, origem rural ou urbana, nacionalidade, além de dados familiares (pai, mãe, filhos, profissão dos mesmos, renda) e dados profissionais.

O quinto passo da pesquisa constou dos encontros para a realização das entrevistas propriamente ditas que aconteceram no mês de dezembro de 2004. Participaram da mesma 48 alunos. Iniciou-se com a apresentação dos objetivos da pesquisa.

Separou-se em seguida os alunos de acordo com suas afinidades, formando quatro grupos, dois de moças e dois de rapazes. Os grupos foram encaminhados para salas separadas, nas quais seriam gravados os debates suscitados pela pergunta norteadora da pesquisa: o que é ser mulher no seu curso e em sua profissão? (pergunta direcionada para as mulheres) e o que é ser homem no seu curso e em sua profissão? (para os homens) Os grupos masculinos, compostos por 4 a 5 rapazes cada um, foram acompanhados por pesquisadores, enquanto os femininos, com 5 a 8 moças, por pesquisadoras. Tendo sido feita a pergunta da pesquisa, 
os pesquisadores/as não fizeram mais nenhuma interferência, limitando-se a gravar as discussões e a anotar os pontos considerados relevantes que poderiam ajudar na posterior transcrição e análise das entrevistas.

Para a interpretação dos resultados da pesquisa de campo foram feitas cerca de dez reuniões com todos os pesquisadores que dela participaram, a fim de se discutir a respeito das categorias que seriam destacadas no artigo, assim como seus conteúdos, tema a ser desenvolvido a seguir.

\section{PARTE 2}

\section{CARACTERIZAÇÃO DOS INFORMANTES ${ }^{14}$}

A caracterização dos informantes é importante para a pesquisa porque permite traçar um perfil a partir de seus dados pessoais e assim conhecer a que universo cultural e socioeconômico os entrevistados pertencem, tendo em vista que estamos trabalhando com o conceito de habitus em que informações dessa natureza são fundamentais.

A partir dos resultados dos questionários, pode-se dizer que o grupo de moças e rapazes entrevistados é constituído por jovens de origem urbana, com uma média de idade compreendida entre 20 e 23 anos, faixa etária prevista para alunos universitários no Brasil. A quase totalidade dos jovens é solteira, pois, dentre os 48 entrevistados, apenas duas alunas e um aluno são casados, o que também é característica da maioria dos estudantes universitários brasileiros.

$\mathrm{O}$ fato de termos praticamente $50 \%$ de alunos e alunas provenientes da rede pública de ensino médio descaracteriza os dados mais gerais dos estudantes universitários, aonde a maioria vem de escolas particulares. No caso do universo desta pesquisa, vê-se que 50\% dos alunos que são provenientes da rede pública fizeram o curso médio no próprio CEFET-PR, instituição que se destaca frente à realidade do ensino público no País, a começar pela grande concorrência para o acesso à instituição, o que é feito por meio de um exame vestibular. Isto significa que estes alunos podem ser

14 Agradecemos a Maria Lúcia Büher Machado, pesquisadora do GeTec, pela elaboração dos quadros aqui apresentados e pelas discussões e colaboração na redação deste item do artigo. 
considerados parte de camadas médias urbanas em processo de ascensão social, o que se confirma se observarmos os dados relativos à ocupação profissional e grau de instrução de seus pais.

\section{- QUADRO II - Dados dos alunos entrevistados}

\begin{tabular}{|c|c|c|c|c|c|c|c|c|c|c|c|c|c|c|c|}
\hline \multirow[t]{2}{*}{ Aluno } & \multirow[t]{2}{*}{ Idade } & \multicolumn{2}{|c|}{ Origem } & \multirow[t]{2}{*}{ Estado civil } & \multicolumn{2}{|c|}{ Filhos } & \multicolumn{2}{|c|}{\begin{tabular}{|l|} 
Curso na \\
UTFPR
\end{tabular}} & \multicolumn{2}{|c|}{ Turno } & \multicolumn{2}{|c|}{ Escolas anteriores } & \multirow[t]{2}{*}{$\begin{array}{c}\text { Profissão/ } \\
\text { ocupação }\end{array}$} & \multicolumn{2}{|c|}{ Remuneração } \\
\hline & & Rural & Urb & & Sim & Não & $\mathrm{A}$ & $\mathrm{B}$ & Manhã & Noite & Pública & Privada & & Sim & Não \\
\hline 01 & 22 & & $\mathrm{x}$ & solteiro & & $x$ & $x$ & & & $\mathrm{x}$ & & $\mathrm{x}$ & estagiário & $\mathrm{x}$ & \\
\hline 02 & 22 & & $\mathrm{x}$ & solteiro & & $x$ & $x$ & & & $x$ & $x^{*}$ & & estagiário & $x$ & \\
\hline 03 & 23 & & $\mathrm{x}$ & solteiro & & $\mathrm{x}$ & & $\mathrm{x}$ & & $x$ & $x^{*}$ & & estagiário & $x$ & \\
\hline 04 & 21 & & $\mathrm{x}$ & solteiro & & $x$ & $\mathrm{x}$ & & & $\mathrm{x}$ & $\mathrm{x}^{*}$ & & Web designer & $x$ & \\
\hline 05 & 24 & & $\mathrm{x}$ & solteiro & & $\mathrm{x}$ & $\mathrm{x}$ & & & $\mathrm{x}$ & $x^{*}$ & & $\begin{array}{l}\text { designer } \\
\text { animação }\end{array}$ & $\mathrm{x}$ & \\
\hline 06 & 24 & & $\mathrm{x}$ & solteiro & & $\mathrm{x}$ & $\mathrm{x}$ & & & $\mathrm{x}$ & & $\mathrm{x}$ & publicitário & $\mathrm{x}$ & \\
\hline 07 & 26 & $\mathrm{x}$ & & solteiro & & $\mathrm{x}$ & $\mathrm{x}$ & & & $\mathrm{x}$ & $\mathrm{x}$ & & artista gráfico & $x$ & \\
\hline 08 & 20 & & $\mathrm{x}$ & solteiro & & $x$ & $x$ & & & $\mathrm{x}$ & $\mathrm{x}$ & & estagiário & $x$ & \\
\hline 09 & 21 & & $\mathrm{x}$ & \begin{tabular}{|l|} 
solteiro \\
\end{tabular} & & $x$ & $x$ & & $x$ & & $\mathrm{x}$ & & \begin{tabular}{|l} 
estudante \\
\end{tabular} & & $x$ \\
\hline 10 & 21 & & $\mathrm{x}$ & solteiro & & $x$ & $\mathrm{x}$ & & $\mathrm{x}$ & & & $\mathrm{x}$ & artista gráfico & $\mathrm{x}$ & \\
\hline 11 & 21 & & $\mathrm{x}$ & solteiro & & $x$ & $x$ & & $\mathrm{x}$ & & $\mathrm{x}$ & $x$ & estudante & & $x$ \\
\hline 12 & 22 & & $\mathrm{x}$ & \begin{tabular}{|l|} 
solteiro \\
\end{tabular} & & $x$ & $x$ & & $x$ & & & $x$ & arte finalista & $x$ & \\
\hline 13 & 22 & & $x$ & solteiro & & $x$ & $x$ & & $\mathrm{x}$ & & & $x$ & estagiário & $x$ & \\
\hline 14 & 20 & & $\mathrm{x}$ & solteiro & & $\mathrm{x}$ & $\mathrm{x}$ & & $\mathrm{x}$ & & $\mathrm{x}^{*}$ & & estagiário & $\mathrm{x}$ & \\
\hline 15 & 21 & & $x$ & solteiro & & $x$ & $x$ & & $\mathrm{x}$ & & $\mathrm{x}$ & & estudante & & $\mathrm{x}$ \\
\hline 16 & 22 & & $x$ & \begin{tabular}{|l|} 
solteiro \\
\end{tabular} & & $x$ & $x$ & & $\mathrm{x}$ & & & $x$ & \begin{tabular}{|l|} 
estudante \\
\end{tabular} & & $\mathrm{x}$ \\
\hline 17 & 22 & & $\mathrm{x}$ & \begin{tabular}{|l|} 
solteiro \\
\end{tabular} & & $x$ & $\mathrm{x}$ & & $\mathrm{x}$ & & & $\mathrm{x}$ & designer free & $x$ & \\
\hline 18 & 23 & & $\mathrm{x}$ & solteiro & & $x$ & $x$ & & $\mathrm{x}$ & & $\mathrm{x}$ & & estudante & $x$ & \\
\hline 19 & 24 & & $\mathrm{x}$ & \begin{tabular}{|l|} 
solteiro \\
\end{tabular} & & $x$ & $x$ & & $\mathrm{x}$ & & $\mathrm{x}$ & $x$ & \begin{tabular}{|l|} 
designer \\
\end{tabular} & $x$ & \\
\hline 20 & 31 & & $\mathrm{x}$ & casado & $\mathrm{x}$ & & $\mathrm{x}$ & & $\mathrm{x}$ & & $\mathrm{x}$ & & $\begin{array}{l}\text { supervisor } \\
\text { diagramação }\end{array}$ & $\mathrm{x}$ & \\
\hline
\end{tabular}

Curso A - Artes Gráficas; Curso B - Tecnologia em Móveis. $\mathrm{X}^{*}$ Escola anterior : CEFET-PR.

- alunos do curso noturno;

- alunos do curso da manhã. 
- QUADRO III - Dados das alunas entrevistadas

\begin{tabular}{|c|c|c|c|c|c|c|c|c|c|c|c|c|c|c|c|}
\hline \multirow[t]{2}{*}{ Aluno } & \multirow[t]{2}{*}{ Idade } & \multicolumn{2}{|c|}{ Origem } & \multirow[t]{2}{*}{ Estado civil } & \multicolumn{2}{|c|}{ Filhos } & \multicolumn{2}{|c|}{$\begin{array}{l}\text { Curso na } \\
\text { UTFPR }\end{array}$} & \multicolumn{2}{|c|}{ Turno } & \multicolumn{2}{|c|}{ Escolas anteriores } & \multirow[t]{2}{*}{$\begin{array}{l}\text { Profissão/ocu- } \\
\text { pação }\end{array}$} & \multicolumn{2}{|c|}{$\begin{array}{l}\text { Remune- } \\
\text { ração }\end{array}$} \\
\hline & & Rural & Urb & & Sim & Não & $\mathrm{A}$ & B & Manhã & Noite & Pública & Privada & & Sim & Não \\
\hline 01 & 20 & $\mathrm{x}$ & & solteira & & $\mathrm{x}$ & & $\mathrm{x}$ & & $\mathrm{x}$ & & $\mathrm{x}$ & Estagiária & $\mathrm{x}$ & \\
\hline 02 & 21 & & $\mathrm{x}$ & solteira & & $\mathrm{x}$ & $\mathrm{x}$ & & & $\mathrm{x}$ & $x^{*}$ & & Estagiária & $\mathrm{x}$ & \\
\hline 03 & 21 & & $\mathrm{x}$ & solteira & & $\mathrm{x}$ & & $\mathrm{x}$ & & $\mathrm{x}$ & $x^{*}$ & & Desen. Projet & $\mathrm{x}$ & \\
\hline 04 & 21 & & $\mathrm{x}$ & solteira & & $\mathrm{x}$ & $\mathrm{x}$ & & & $\mathrm{x}$ & & $\mathrm{x}$ & $\begin{array}{l}\text { Designer/ } \\
\text { Prof }{ }^{\text {mat. }}\end{array}$ & $\mathrm{x}$ & \\
\hline 05 & 20 & & $\mathrm{x}$ & solteira & & $\mathrm{x}$ & & $\mathrm{x}$ & & $x$ & $x$ & & Secretária & $\mathrm{x}$ & \\
\hline 06 & 20 & $\mathrm{NI}$ & & solteira & & $\mathrm{NI}$ & $\mathrm{x}$ & & & $\mathrm{x}$ & & $\mathrm{x}$ & $\begin{array}{l}\text { Estagiária/ } \\
\text { Fun.públ. }\end{array}$ & $\mathrm{x}$ & \\
\hline 07 & 20 & & $\mathrm{x}$ & solteira & & $\mathrm{x}$ & & $\mathrm{x}$ & & $\mathrm{x}$ & $\mathrm{x}$ & & fotógrafa & $\mathrm{x}$ & \\
\hline 08 & 34 & & $\mathrm{x}$ & casada & & $\mathrm{x}$ & $\mathrm{x}$ & & & $\mathrm{x}$ & $\mathrm{x}^{* * *}$ & & Estagiária & $\mathrm{x}$ & \\
\hline 09 & 21 & & $\mathrm{x}$ & solteira & & $\mathrm{NI}$ & & $\mathrm{x}$ & & $\mathrm{x}$ & & $\mathrm{x}$ & Projetista & $\mathrm{x}$ & \\
\hline 10 & 22 & & $\mathrm{x}$ & solteira & & $\mathrm{x}$ & & $\mathrm{x}$ & & $\mathrm{x}$ & $\mathrm{x}$ & & Projetista & & $\mathrm{x}$ \\
\hline 11 & 22 & & $\mathrm{x}$ & solteira & & $\mathrm{x}$ & & $\mathrm{x}$ & & $\mathrm{x}$ & $x^{*}$ & & $\begin{array}{l}\text { Téc. Des. } \\
\text { industrial }\end{array}$ & $\mathrm{x}$ & \\
\hline 12 & 21 & & $\mathrm{x}$ & solteira & & $\mathrm{x}$ & $\mathrm{x}$ & & & $\mathrm{x}$ & & $\mathrm{x}$ & Estudante & & $\mathrm{x}$ \\
\hline 13 & 22 & & $\mathrm{x}$ & solteira & & $\mathrm{x}$ & & $\mathrm{x}$ & & $\mathrm{x}$ & & $x$ & Estudante & & $x$ \\
\hline 14 & 23 & & $\mathrm{x}$ & casada & & $\mathrm{x}$ & & $\mathrm{x}$ & & $\mathrm{x}$ & $\mathrm{x}$ & & $\begin{array}{l}\text { Tecnóloga/ } \\
\text { Secretária }\end{array}$ & $\mathrm{x}$ & \\
\hline 15 & 20 & & $\mathrm{x}$ & solteira & & $\mathrm{x}$ & $\mathrm{x}$ & & & $\mathrm{x}$ & & $x$ & Estagiária & $\mathrm{x}$ & \\
\hline 16 & 21 & & $\mathrm{x}$ & solteira & & $\mathrm{x}$ & & $\mathrm{x}$ & & $\mathrm{x}$ & $\mathrm{x}$ & & Estudante & & $\mathrm{x}$ \\
\hline 17 & 21 & & $\mathrm{x}$ & solteira & & $\mathrm{x}$ & & $\mathrm{x}$ & & $\mathrm{x}$ & & $\mathrm{x}$ & Projetista & $\mathrm{x}$ & \\
\hline 18 & 21 & & $\mathrm{x}$ & solteira & & $\mathrm{x}$ & $\mathrm{x}$ & & $\mathrm{x}$ & & $\mathrm{x}$ & & $\begin{array}{l}\text { Estagiária } \\
\text { Infografia }\end{array}$ & $\mathrm{x}$ & \\
\hline 19 & 21 & & $\mathrm{x}$ & solteira & & $\mathrm{x}$ & $\mathrm{x}$ & & $x$ & & & $x$ & Estagiária & $\mathrm{x}$ & \\
\hline 20 & 22 & & $\mathrm{x}$ & solteira & & $\mathrm{x}$ & $x$ & & $x$ & & $x$ & & Desepregada & & $\mathrm{x}$ \\
\hline 21 & 23 & & $\mathrm{x}$ & solteira & & $\mathrm{x}$ & $\mathrm{x}$ & & $\mathrm{x}$ & & $x$ & & $\begin{array}{l}\text { Designer } \\
\text { Gráfica }\end{array}$ & $\mathrm{x}$ & \\
\hline 22 & 23 & & $\mathrm{x}$ & casada & & $\mathrm{x}$ & $\mathrm{x}$ & & $\mathrm{x}$ & & $x^{*}$ & & Aeroviária & $\mathrm{x}$ & \\
\hline 23 & 27 & & $\mathrm{x}$ & solteira & & $\mathrm{x}$ & $x$ & & $x$ & & & $\mathrm{x}$ & Artista gráfica & $\mathrm{NI}$ & \\
\hline 24 & 20 & & $x$ & solteira & & $x$ & & $\mathrm{x}$ & $x$ & & & $x$ & Artista plástica & $x$ & \\
\hline 25 & 21 & & $\mathrm{x}$ & solteira & & $\mathrm{x}$ & & $\mathrm{x}$ & $x$ & & $x^{*}$ & & $\mathrm{NI}$ & $\mathrm{NI}$ & \\
\hline 26 & 21 & & $\mathrm{x}$ & solteira & & $\mathrm{x}$ & & $\mathrm{x}$ & $x$ & & & $\mathrm{x}$ & Estagiária & $\mathrm{x}$ & \\
\hline 27 & 21 & & $x$ & solteira & & $\mathrm{x}$ & & $\mathrm{x}$ & $x$ & & & $x$ & $\mathrm{NI}$ & $\mathrm{NI}$ & \\
\hline 28 & 23 & & $x$ & solteira & & $\mathrm{x}$ & & $\mathrm{x}$ & $x$ & & $\mathrm{x}$ & & $\mathrm{NI}$ & $\mathrm{NI}$ & \\
\hline
\end{tabular}

Curso A - Artes Gráficas; Curso B - Tecnologia em Móveis; $\mathrm{X}^{*}$ formação no CEFET-PR; $\mathrm{X}^{* *}$ Formação Superior.

\section{- alunas do período da noite;}

- alunas do período da manhã. 
Praticamente a totalidade das alunas entrevistadas do Curso de Tecnologia em Desenho de Móveis é do sexo feminino, tendo em vista que dentre o total de 17 entrevistadas/os desse curso, encontramos apenas um rapaz. A maioria dos rapazes informantes está cursando Tecnologia em Artes Gráficas, onde encontramos um número mais equilibrado por sexo, ou seja, 12 moças e 19 rapazes. Portanto, dentre os 20 rapazes entrevistados temos 19 que estão cursando Tecnologia em Artes Gráficas, o que significa que as representações de gênero a partir da ótica masculina, que serão aqui apresentadas e analisadas, referem-se basicamente ao universo deste Curso. Para o universo feminino de um total de 28 moças, 12 estão cursando Tecnologia em Artes Gráficas e 16 estão no Curso de Tecnologia em Desenho de Móveis.

A atividade profissional dos informantes ocorre, em sua maioria, em estágios ou em atividades relacionadas ao curso que fazem. Pode-se dizer que grande parte deles está em período de treinamento. Dentre as moças podemos verificar que mais de $50 \%$ trabalha e são remuneradas, porém, dentre as funções ocupadas aponta-se alguns postos que, na maioria das vezes, são caracterizados como "funções femininas", como secretária e professora, além de não haver nenhuma indicação de algum posto de comando ocupado pelas mulheres entrevistadas. Destacase a função de projetista para as alunas do curso de Tecnologia em Desenho de Móveis, sendo que, uma delas desempenha essa função como estagiária, sem remuneração.

Quanto aos rapazes, podemos observar que, embora nem todo o grupo trabalhe, todos os que trabalham, mesmo que seja como estagiários, são remunerados, fato que não ocorre com o grupo feminino.Também é entre o grupo masculino que encontramos uma função de comando supervisor de diagramação - posto este ocupado pelo aluno mais velho do grupo entrevistado, o único com 31 anos de idade. Se estabelecermos uma comparação entre os dois grupos, poderemos observar que entre as mulheres, a mais velha, com 34 anos de idade e que já possui uma formação superior anterior, ocupa a função de estagiária. Para uma interpretação mais aprofundada deste fato seria necessária uma melhor contextualização; no entanto, se tomarmos como base os questionários preenchidos pelos 
alunos e alunas, teremos alguns indícios quanto às questões pertinentes às relações de gênero e à eqüidade no mercado de trabalho, fatores que serão esclarecidos a partir dos conteúdos das entrevistas.

\section{- QUADRO IV - Dados familiares dos alunos entrevistados}

\begin{tabular}{|c|c|c|c|c|c|c|c|c|c|c|c|c|}
\hline \multirow[t]{3}{*}{ Aluno } & \multicolumn{4}{|c|}{ Origem } & \multicolumn{2}{|c|}{$\begin{array}{c}\text { Origem } \\
\text { étnico - racial }\end{array}$} & \multicolumn{2}{|c|}{ Idade } & \multicolumn{2}{|c|}{ Profissão ou Ocupação } & \multicolumn{2}{|c|}{ Grau de instrução } \\
\hline & \multicolumn{2}{|c|}{ Pai } & \multicolumn{2}{|c|}{ Mãe } & Pai & Mãe & Pai & Mãe & Pai & Mãe & Pai & Mãe \\
\hline & $\mathrm{U}$ & $\mathrm{R}$ & $\mathrm{U}$ & $\mathrm{R}$ & & & & & & & & \\
\hline 01 & & $\mathrm{x}$ & & $\mathrm{x}$ & germânica & argentina & 52 & 53 & autônomo & dona de casa & superior & $2^{\circ}$ grau inc. \\
\hline 02 & $\mathrm{x}$ & & $\mathrm{x}$ & & italiana & $\mathrm{NI}$ & 45 & 47 & contador & aux. escritório & superior & $2^{\circ}$ grau \\
\hline 03 & & $\mathrm{x}$ & $\mathrm{NI}$ & & $\begin{array}{l}\text { polonesa/ } \\
\text { italiana }\end{array}$ & $\begin{array}{l}\text { ucraniana/ } \\
\text { negra/indígena }\end{array}$ & 49 & 47 & \begin{tabular}{|l|} 
auxiliar \\
administrativo
\end{tabular} & $\mathrm{NI}$ & $2^{\circ}$ grau & $2^{\circ}$ grau inc. \\
\hline 04 & & $\mathrm{x}$ & & $\mathrm{x}$ & parda & parda & 55 & 50 & administrador & professora & superior & superior \\
\hline 05 & & $\mathrm{x}$ & $\mathrm{x}$ & & polonesa & afro-brasil & 59 & 50 & func. público & func. público & superior & $2^{\circ}$ grau \\
\hline 06 & $\mathrm{x}$ & & $\mathrm{x}$ & & mista & mista & 44 & 46 & pastor/admin. & do lar & superior & $2^{\circ}$ grau \\
\hline 07 & $\mathrm{x}$ & & $\mathrm{x}$ & & $\mathrm{NI}$ & $\mathrm{NI}$ & 59 & 54 & comerciante & bancária & sup. inc. & pós \\
\hline 08 & & $\mathrm{x}$ & & $\mathrm{x}$ & alemã & alemã & 75 & 71 & agricultor & agricultora & fundamental & fundamental \\
\hline 09 & & $\mathrm{x}$ & $\mathrm{x}$ & & $\begin{array}{l}\text { francesa/ } \\
\text { branca européia }\end{array}$ & branca européia & 53 & 47 & eng.florestal & inst. yoga & mestre & $\begin{array}{l}2^{\circ} \text { grau } \\
\text { técn. }\end{array}$ \\
\hline 10 & & $\mathrm{x}$ & & $\mathrm{x}$ & \begin{tabular}{|l|} 
polonesa \\
\end{tabular} & indígena & 48 & 46 & vendedor & do lar & $2^{\circ}$ grau & $2^{\circ}$ grau inc. \\
\hline 11 & $\mathrm{x}$ & & $x$ & & brasileira & brasileira & 45 & 49 & administração & func. admin. & técnico & técnico \\
\hline 12 & $\mathrm{x}$ & & $\mathrm{x}$ & & alemã & $\begin{array}{l}\text { italiana/ } \\
\text { portuguesa }\end{array}$ & 57 & 54 & técnico & professora & $1^{\circ}$ grau & pós-grad. \\
\hline 13 & $\mathrm{x}$ & & $\mathrm{x}$ & & italiana & $\begin{array}{l}\text { portuguesa/ } \\
\text { indígena }\end{array}$ & 54 & 47 & $\begin{array}{l}\text { professor } \\
\text { universitário }\end{array}$ & $\begin{array}{l}\text { professora } \\
\text { universitária }\end{array}$ & doutorado & mestrado \\
\hline 14 & & $\mathrm{x}$ & $\mathrm{x}$ & & japonesa & $\begin{array}{l}\text { portuguesa/ } \\
\text { indígena }\end{array}$ & 60 & 58 & aposentado & do lar & superior & $2^{\circ}$ grau \\
\hline 15 & & $\mathrm{x}$ & & $\mathrm{x}$ & italiana & italiana & $\mathrm{NI}$ & 51 & $\mathrm{NI}$ & confeccionista & $1^{\circ} \mathrm{grau}$ & $2^{\circ}$ grau \\
\hline 16 & & $\mathrm{x}$ & & $\mathrm{x}$ & $\begin{array}{l}\text { branca } \\
\text { espanhola }\end{array}$ & branca/alemã & $\begin{array}{c}\text { Fa- } \\
\text { lecido }\end{array}$ & 4 & metalúrgico & do lar & primário & $2^{\circ}$ grau inc. \\
\hline 17 & $\mathrm{x}$ & & $\mathrm{x}$ & & alemã & polonesa & 58 & 54 & bancário & do lar & superior & $2^{\circ}$ grau \\
\hline 18 & $\mathrm{x}$ & & $\mathrm{x}$ & & italiana & $\begin{array}{l}\text { indígena/ } \\
\text { portuguesa }\end{array}$ & 52 & $\mathrm{NI}$ & médico & secretária & superior & $2^{\circ}$ grau \\
\hline 19 & $\mathrm{NI}$ & & $\mathrm{NI}$ & & européia & $\begin{array}{l}\text { indígena/ } \\
\text { européia }\end{array}$ & 60 & 49 & eng. civil & func. pública & superior & superior \\
\hline 20 & $\mathrm{x}$ & & $\mathrm{x}$ & & portuguesa & espanhola & 60 & 49 & militar apos. & dona de casa & $2^{\circ} \mathrm{grau}$ & $2^{\circ}$ grau \\
\hline
\end{tabular}

$$
\text { U - Urbana; R - Rural. }
$$

- alunos do curso noturno;

- alunos do curso da manhã. 


\section{- QUADRO V - Dados familiares das alunas entrevistadas}

\begin{tabular}{|c|c|c|c|c|c|c|c|c|c|c|c|c|}
\hline \multirow[t]{3}{*}{ Aluno } & \multicolumn{4}{|c|}{ Origem } & \multicolumn{2}{|c|}{$\begin{array}{c}\text { Origem } \\
\text { étnico - racial }\end{array}$} & \multicolumn{2}{|c|}{ Idade } & \multicolumn{2}{|c|}{ Profissão ou Ocupação } & \multicolumn{2}{|c|}{ Grau de instrução } \\
\hline & \multicolumn{2}{|c|}{ Pai } & \multicolumn{2}{|c|}{ Mãe } & Pai & Mãe & Pai & Mãe & Pai & Mãe & Pai & Mãe \\
\hline & $\mathrm{U}$ & $\mathrm{R}$ & $\mathrm{U}$ & $\mathrm{R}$ & & & & & & & & \\
\hline 01 & $\mathrm{x}$ & & & $\mathrm{x}$ & branca/italiana & alemã/taliana & 49 & 46 & professor & professora & superior & superior \\
\hline 02 & & $\mathrm{x}$ & $\mathrm{x}$ & & branca & branca & 50 & 46 & agricultor & bancária & $1^{\circ}$ grau & superior \\
\hline 03 & $\mathrm{x}$ & & $\mathrm{x}$ & & branca & branca & 58 & 53 & autônomo & artesã & superior & superior \\
\hline 04 & $\mathrm{x}$ & & $\mathrm{x}$ & & $\mathrm{NI}$ & italiana & 54 & 51 & $\begin{array}{l}\text { consultor } \\
\text { aposentado }\end{array}$ & doceira & $2^{\circ}$ grau & $1^{\circ}$ grau \\
\hline 05 & $\mathrm{x}$ & & $\mathrm{x}$ & & japonesa & japonesa & 51 & 45 & corretor imóveis & bancária & $2^{\circ}$ grau & $1^{\circ}$ grau \\
\hline 06 & $\mathrm{x}$ & & $\mathrm{x}$ & & chinesa & chinesa & 51 & 47 & autônomo & do lar & $2^{\circ} \mathrm{grau}$ & $2^{\circ}$ grau \\
\hline 07 & $\mathrm{x}$ & & $\mathrm{x}$ & & branca & branca & 47 & 45 & bancário/professor & $\mathrm{NI}$ & mestre & superior \\
\hline 08 & & $\mathrm{x}$ & & $\mathrm{x}$ & italiana & italiana & 57 & 43 & aposentado & comerciante & $2^{\circ} \mathrm{grau}$ & $2^{\circ}$ grau \\
\hline 09 & & $\mathrm{x}$ & & $\mathrm{x}$ & japonesa & japonesa & 57 & 49 & agricultor & dona de casa & superior & $2^{\circ}$ grau \\
\hline 10 & & $\mathrm{x}$ & & $\mathrm{x}$ & polonesa & polonesa & 56 & 55 & relojoeiro & professora & superior inc. & pós \\
\hline 11 & & $x$ & $\mathrm{x}$ & & negra/indígena & italiana & 50 & 43 & $\begin{array}{l}\text { engenheiro } \\
\text { mecânico }\end{array}$ & do lar & superior & $1^{\circ}$ grau inc. \\
\hline 12 & & $\mathrm{x}$ & $\mathrm{x}$ & & $\begin{array}{l}\text { portuguesa/ } \\
\text { espanhola }\end{array}$ & italiana & 65 & 58 & aposentado & professora & $\begin{array}{l}2^{\circ} \text { grau } \\
\text { incomp. }\end{array}$ & superior \\
\hline 13 & $\mathrm{x}$ & & $\mathrm{x}$ & & alemã & alemã & 47 & 49 & vendedor & vendedora & $2^{\circ} \mathrm{grau}$ & $1^{\circ}$ grau \\
\hline 14 & $\mathrm{x}$ & & $\mathrm{x}$ & & japonesa & japonesa & 62 & 55 & engenheiro civil & professora & superior & superior \\
\hline 15 & $\mathrm{x}$ & & $\mathrm{x}$ & & japonesa & japonesa & 46 & 43 & sócio-diretor & economiária & superior inc. & $\begin{array}{l}\text { superior } \\
\text { Inc. }\end{array}$ \\
\hline 16 & $\mathrm{x}$ & & $\mathrm{x}$ & & portuguesa & $\begin{array}{l}\text { portuguesa/ } \\
\text { italiana }\end{array}$ & 71 & 65 & adm. empresas & professora & superior & magistério \\
\hline 17 & $\mathrm{x}$ & & $\mathrm{x}$ & & $\begin{array}{l}\text { indígena/ } \\
\text { alemã }\end{array}$ & $\begin{array}{l}\text { portuguesa/ } \\
\text { italiana }\end{array}$ & 50 & 48 & empresário & empresária & $2^{\circ}$ grau & $1^{\circ}$ grau \\
\hline 18 & & $\mathrm{x}$ & & $\mathrm{x}$ & $\begin{array}{l}\text { italiana/ } \\
\text { polonesa }\end{array}$ & italiana & 44 & 43 & vendedor & professora & primário & superior \\
\hline 19 & $\mathrm{x}$ & & $\mathrm{x}$ & & $\begin{array}{l}\text { negra/indígena/ } \\
\text { portuguesa }\end{array}$ & $\begin{array}{l}\text { italiana/ } \\
\text { polonesa }\end{array}$ & 57 & 52 & economista & economista & doutorado & mestrado \\
\hline 20 & $\mathrm{x}$ & & $\mathrm{x}$ & & italiana & indígena & 54 & 51 & representante & professora & superior & superior \\
\hline 21 & & $\mathrm{x}$ & $\mathrm{x}$ & & branca & branca & 63 & 57 & aposentado & dona de casa & $1^{\circ}$ grau & $1^{\circ} \mathrm{grau}$ \\
\hline 22 & $\mathrm{x}$ & & $\mathrm{x}$ & & italiana & brasileira & 53 & 46 & aposentado & dona de casa & $1^{\circ}$ grau & $1^{\circ} \mathrm{grau}$ \\
\hline 23 & & $\mathrm{x}$ & $\mathrm{x}$ & & branca & branca & 68 & 57 & comerciante & dona de casa & $2^{\circ}$ grau & $2^{\circ} \mathrm{grau}$ \\
\hline 24 & $\mathrm{x}$ & & $\mathrm{x}$ & & $\begin{array}{l}\text { alemã/ } \\
\text { portuguesa }\end{array}$ & italiana & 54 & 43 & analista sistema & economista & superior & superior \\
\hline 25 & $\mathrm{x}$ & & $\mathrm{x}$ & & espanhola & $\begin{array}{l}\text { portuguesa/ } \\
\text { indígena }\end{array}$ & 60 & 56 & $\mathrm{NI}$ & professora & $2^{\circ}$ grau & superior \\
\hline 26 & $\mathrm{x}$ & & $\mathrm{x}$ & & branca & banca & 54 & 50 & contador & rep. comercial & superior & superior \\
\hline 27 & & $\mathrm{x}$ & & $\mathrm{x}$ & $\begin{array}{l}\text { portuguesa/ } \\
\text { indígena }\end{array}$ & japonesa & 47 & 49 & advogado & gerente administ. & superior & superior \\
\hline 28 & $\mathrm{x}$ & & & $\mathrm{x}$ & alemã & italiana & 47 & 57 & autônomo & aposentada & $2^{\circ}$ grau inc. & $2^{\circ} \mathrm{grau}$ \\
\hline
\end{tabular}

$$
\text { U - Urbana; R - Rural. }
$$

- alunas do período da noite;

- alunas do período da manhã. 
Os dados familiares são importantes, porque é na família que as pessoas recebem os primeiros padrões de sociabilidade e também os valores e regras de comportamento que quase sempre constituem referência para toda a vida. Com certeza os padrões de gênero estão incluídos nestas referências.

Quanto à origem dos pais e mães dos alunos e alunas entrevistados observa-se que há um número significativo de pessoas vindas da área rural, logo, podemos avaliar que os familiares dos entrevistados passaram pelo processo de migração, característica de muitos habitantes das áreas urbanas do País. A idade dos pais e mães está compreendida entre os 44 e 60 anos, sendo que, dentre as mães, apenas duas possuem mais de 60 anos. É interessante observar que em apenas 05 casos a mãe é mais velha do que 0 pai, e mesmo assim, é uma pequena diferença (não mais do que dois anos). Todos os outros pais são mais velhos do que as mães, o que revela que, com relação à idade do casal, essas famílias seguem o modelo tradicional, em que o marido é mais velho do que a mulher. Este fato pode levar a uma ascendência do pai sobre a mãe, que marca as relações familiares.

O grau de instrução dos pais e mães dos/as entrevistados/as também merece destaque, tendo em vista que quase $50 \%$ possuem formação superior, ainda que haja um maior número de pais com esse nível de escolaridade. Também aqui se revela a superioridade dos pais em relação às mães, confirmando mais uma vez o modelo tradicional de família em que geralmente o marido, por ser considerado o responsável pelo sustento da família, possui formação escolar superior à da mulher. $\mathrm{O}$ número de pais $\mathrm{e}$ mães que estudaram somente até o ensino fundamental é menor do que os que concluíram o ensino médio.

Ao observarmos os dados que indicam a profissão ocupada por pais e mães, as informações apresentadas acima sobre os filhos, que apontavam para um grupo com condições socioeconômicas correspondentes às camadas médias altas, se confirmam. Médicos, engenheiros, administradores, empresários são algumas das profissões dos pais do grupo entrevistado. Todas as mães que possuem formação superior trabalham fora, como professoras universitárias, bancárias, gerente-administrativa, funcionáriaspúblicas. Sob este aspecto pode-se dizer que elas exercem uma influência 
de transformação quanto às relações de gênero da família tradicional aonde geralmente a mulher não exerce atividade profissional. No entanto, é neste item que também podemos observar como os papéis de gênero ainda interferem nas funções ocupadas por homens e mulheres no mercado de trabalho, pois entre as 48 mães indicadas, 13 constam como "do lar", ou "dona-de-casa" inclusive as que têm o ensino médio completo.

Identificar a origem étnico-racial das pessoas no Brasil é uma tarefa complexa, diante da diversidade da formação da sociedade brasileira que possui inúmeras influências desde as das populações indígenas, até as dos povos africanos que vieram durante o período da escravidão, além dos europeus e asiáticos. Todos juntos contribuem para o caleidoscópio cultural que é nossa população, que se caracteriza cada vez mais pela mestiçagem e hibridização. No entanto, considerando as declarações dos/ as entrevistados/as, podemos observar a preponderância branca, cujas nacionalidades são majoritariamente provenientes de países europeus. Foi indicada somente uma mãe de origem afro-brasileira, e um pai e mãe pardo/a (mestiço/a de índio ou negro com branco). A origem indígena surge como uma das mesclas raciais dos familiares do grupo entrevistado. A origem étnico-racial é importante, porque tem íntima relação com características culturais que, por sua vez, influenciam os padrões de gênero de um determinado grupo. Certamente as representações sobre as relações de gênero que serão tratadas mais adiante têm forte influência das origens aqui apontadas pelos entrevistados.

Embora esses dados de caracterização não sejam a principal base para análise do grupo pesquisado, as informações provenientes dos questionários auxiliam a traçar um perfil geral do grupo, o que pode contribuir para a interpretação e leitura das percepções e considerações que emergiram nas entrevistas. Dessa forma, em uma primeira análise, podemos observar que se trata de um grupo seleto, se tomarmos como referência a realidade da maioria dos/as estudantes brasileiros/as. $\mathrm{O}$ fato de terem chegado a um curso de nível superior em uma instituição pública de difícil acesso, além de terem vindo, em sua maioria, de uma formação escolar da rede privada de ensino, revelam sua posição social. Outro indicativo de que os entrevistados pertencem às camadas sociais elevadas, se comparados com a maioria da 
população brasileira, é o fato de fazerem parte de famílias cujos pais e mães possuem uma trajetória de busca e valorização da educação superior. O número significativo de pais e mães com formação universitária, sendo a maioria profissionais liberais em exercício, também permite dizer que os informantes desta pesquisa pertencem a uma camada socioeconômica privilegiada da sociedade brasileira.

\section{RESULTADOS DAS ENTREVISTAS ${ }^{15}$}

Neste item serão apresentadas as representações ${ }^{16}$ dos alunos e das alunas que participaram das entrevistas, tal como foram explicitadas por eles e elas. Num primeiro subitem, evitou-se fazer comentários sobre suas opiniões, procurando trazer ao leitor a idéia mais próxima possível de como os/as informantes se manifestaram, utilizando inclusive, em vários momentos, trechos de suas falas, a fim de transmitir as expressões utilizadas por eles. Este método de redação dos resultados da pesquisa qualitativa é importante porque os informantes muitas vezes dizem mais claramente o que pensam em expressões verbais e nas entrelinhas do que propriamente em respostas a perguntas formais.

As categorias retiradas das entrevistas para a organização da descrição e interpretação de seus resultados foram as seguintes: a) representações das alunas sobre as mulheres e os homens; b) representações dos alunos sobre os homens e as mulheres; c) representações dos alunos sobre as relações de gênero no curso e na profissão e d) representações das alunas sobre as relações de gênero no curso e na profissão.

No segundo subitem, apresenta-se a interpretação dos resultados encontrados.

15 Agradecemos a Maria Juracy Aires, Sivonei Hidalgo, Maria Lúcia B. Machado, Lindamir Salete Casagrande e Ronaldo de Oliveira Corrêa, pesquisadoras e pesquisador do GeTec, pela participação nas discussões e interpretação dos resultados da pesquisa e pelas idéias que enriqueceram o texto.

16 O termo representação neste artigo é utilizado para designar as interpretações dos fenômenos sociais criadas pelos indivíduos em seu dia-a dia, assim como a constituição e compartilhamento de significados que são expressos através das práticas cotidianas (GEERTZ, 1978). 
a) Representações das alunas sobre as mulheres e os homens.

Ao analisar as entrevistas das mulheres, observa-se que elas se vêem como mais sensíveis, frágeis, pacientes, delicadas, caprichosas, criativas e flexíveis que os homens.

Consideram-nas também preconceituosas, arrogantes, faladeiras, fofoqueiras e "chatinhas". Percebem as mulheres como mais preocupadas, cuidadosas e detalhistas, fatores que contam como pontos positivos para que elas se desenvolvam dentro da profissão. A falta de força física foi um comentário recorrente nas entrevistas, e foi visto negativamente porque limita o desempenho das mulheres em determinadas funções e coloca-as em desvantagem em relação aos homens, "na hora de montar móveis talvez ser mulher dificulte um pouquinho na força física...". Porém, outras comentaram que a falta de força não as impediu de carregarem "pra baixo e pra cima" um protótipo de móveis que fizeram e que ficou muito pesado, "se o pessoal visse não ia dizer que é só curso pra mulherzinha, porque a gente coloca a mão na massa... a gente se vira sem os homens".

As entrevistadas observam 0 avanço da participação feminina no mercado de trabalho e no mundo acadêmico em todos os setores, o que pode ser notado na fala de uma entrevistada quando diz que "as mulheres estão tomando conta do mundo". Entretanto reconhecem que o mercado valoriza mais os designers masculinos do que as femininas. Segundo elas, os homens preferem as mulheres para vender os projetos de cozinha. No setor de decoração também elas são bem aceitas, "mulher é bem difícil de ver reconhecida no mercado, a não ser que faça decoração... e também projetista e desenhista...". Consideram isso como um preconceito e assumem que elas (as mulheres) também têm preconceito e que devem superá-los para poder mostrar melhor seu trabalho.

Reconhecem a dificuldade de freqüentar cursos que têm predominância masculina como as engenharias, "quando você tem mais mulher por perto você se sente mais segura dentro do grupo... você tem mais liberdade de falar certas coisas... se você está num lugar que tem só homem você fica mais retraída..”. 
Consideraram também a dificuldade que os rapazes têm de freqüentarem cursos com predominância feminina como o de Tecnologia em Desenho de Móveis. Os que entraram neste curso (predominantemente feminino) não continuaram o curso. Para algumas foi porque não suportaram um ambiente com muitas mulheres. “...ele parecia um alienígena na sala. Ele falou: 'ou eu saio ou eu mudo de curso'. Aí ele mudou de curso”. Em minoria, não se sentiram bem. "Todos os que entraram saíram. Desistiram”. Isto porque não suportam a pressão social, pois têm que enfrentar preconceitos e são rotulados de homossexuais.

Por outro lado, as mulheres consideram os homens mais firmes e discretos, observam ainda que eles simplificam as coisas, o que agrega valor ao seu trabalho. De acordo com a percepção delas, os homens estão mais voltados para trabalhos pesados, que exigem força física. Eles vão estudar cursos como engenharia porque se dão melhor em áreas técnicas e das ciências exatas. Interessam-se mais para trabalhar com computadores e por programação.

As alunas entrevistadas disseram que na vida profissional os homens destacam-se mais do que as mulheres. Na área de design, por exemplo, onde há um número razoável de mulheres, os homens são os profissionais mais reconhecidos. Segundo elas os homens são mais firmes em suas posições profissionais, são mais discretos, têm idéias "geniais" e eles não complicam os trabalhos, apesar de serem também mais desorganizados e nem sempre terem muito capricho. "a letra de menino sempre é mais feia..." (risos). Quando se tem que representar uma empresa, "os homens são os que vão falar no palco”. São eles que gerenciam a empresa, estão na direção e no comando.

Com relação a estágios, segundo as alunas, há uma nítida preferência pelos homens. As empresas que buscam estagiários nos cursos (a maioria homens) contratam muito mais os rapazes do que as alunas. “... veio aqui e ofereceu estágio pra todo mundo e só pegou homens”.

Esta pode ser uma razão para o fato de serem os homens, em sua maioria, os que ocupam posições de chefia, pois "antigamente era só homem, só homem..." Para elas isto é reflexo da sociedade e sua história que sempre foi muito machista e sempre deu mais preferência para os homens profissionais. "Isto é reflexo da sociedade anterior..." 
Foi falado também de um certo preconceito que existe para com o homem que estuda design, por ser considerado homossexual, talvez porque trabalha com desenho e ilustração. Segundo elas, os designers são mais cuidadosos e mais delicados. Porém, "isto (o fato dos designers serem vistos como gays) não tem nada a ver, os trabalhos dele (um colega) são superbonitos. É preconceito mesmo".

b) Representações dos alunos sobre homens e mulheres

Foi marcante na percepção dos homens a importância que assume para eles obrigações que lhes são cobradas pela sociedade a respeito de seu papel de provedor. Para eles, a responsabilidade de um homem se manifesta pelo cumprimento de seu papel de homem que é o de sustentar uma família e dar-lhe segurança financeira. Para isto, eles têm que estudar, se formar e trabalhar. Esta maneira de pensar foi unânime nas falas masculinas, sendo um dos temas mais enfatizados por eles. Colocar dinheiro em casa é uma responsabilidade do homem. "o homem...sempre foi ter que cuidar de uma família e hoje em dia não é muito diferente disso não... têm que ter essa responsabilidade".

Como conseqüência desta visão, assumir a situação de ser um homem sustentado por mulher é complicado em função da percepção do papel masculino de provedor e, também, porque, segundo alguns, haveria muita cobrança, não só dos familiares, mas também da sociedade em geral. "Imagine a mulher sustentando o homem, chamam o cara de sanguessuga, de vagabundo... os homens concordam comigo...".

Para alguns, este é o sonho de futuro: ter uma família que ele seja o provedor, aquele que dá segurança e conforto, inclusive, de preferência com a possibilidade da mulher não precisar trabalhar profissionalmente. Nenhum deles fez referências a ser contra o fato de sua mulher trabalhar fora, porém para muitos, o ideal é que isto não seja necessário.”... “É um anseio meu, de realização profissional conseguir atingir um cargo, um nível profissional, um patamar de poder sustentar minha família de uma maneira satisfatória, que eu possa dar o estudo, a casa, momentos de lazer para a família... acho que seria uma realização pessoal...". 
No entanto, esta não foi uma opinião unânime, porque um deles afirmou que não teria nenhum problema, caso sua mulher fosse mais bem remunerada do que ele, dizendo, inclusive, que concorda com a possibilidade de sair do trabalho para cuidar dos filhos, caso houvesse necessidade. Mas, ainda assim, houve afirmações como esta: "Eu não tenho problema nenhum com relação a ganhar menos, acho que conseguiria enfrentar a situação de desemprego com a mulher trazendo pra casa o sustento sem nenhum problema. Mas consciente ou inconscientemente acho que os homens de um modo geral querem estar bem, querem poder trazer pra casa uma condição boa de vida..." Outros revelaram que a participação das mulheres no mercado de trabalho estava criando uma competição entre eles, prejudicando-os: "hoje o homem ainda é obrigado manter a família e, ainda assim, ele é obrigado a concorrer com as mulheres, de quem ele é cobrado a cuidar".

As opiniões sobre o trabalho das mulheres foram bastante ambíguas e contraditórias. Percebe-se uma preocupação em não demonstrar um pensamento machista, porém muitas vezes ouviu-se frases como: “... acredito que tá certo que elas têm que trabalhar também, não é só a gente... Mas elas deviam ficar nos cargos menores. Mas, daí, deixar os cargos mais altos pro marido receber mais".

Alguns revelaram uma preocupação com a saída da mulher para 0 mercado de trabalho e a falta de sua presença na família. "O problema disso é que as mulheres estão se afastando da família. Os filhos não estão sendo bem criados e crescidos". Neste contexto, a idéia é de que o homem teria que sustentar a família para que a mulher possa criar bem seus filhos.

Como esta não é uma opinião unânime, outros consideraram que estas coisas estão mudando e que não precisa ser necessariamente da forma mais tradicional. Segundo estes, "depende muito da cabeça de cada um”. Neste caso, se a pessoa está trabalhando e tiver filhos, vai ter que entrar num acordo com o parceiro para saber quem cuidará da criança. "Se eu for casado e nós dois trabalhando... Eu acho que um dos dois vai ter que largar o emprego... ou trabalhar meio período pra ajudar". Poucos admitiram fazer o trabalho doméstico. Nestes casos o exemplo dos pais foi marcante, pois as referências citadas sempre eram 
as da família de origem. Meu pai realmente trabalhava integralmente... desde manhã, ia pra casa almoçar e ia embora e voltava de noite pra casa e dormia. Assistia jornal e dormia. Acho que ser homem é isso, não é dar porrada na mulher."

A força física foi uma característica masculina bastante citada para apontar as diferenças entre homens e mulheres. Para tanto, a alegação da ciência foi utilizada, assim como para enfatizar outras diferenças "é cientificamente comprovado, o homem tem uma organização espacial, senso de orientação espacial muito melhor que a mulher. Inclusive para dirigir".(risos)

Outras diferenças entre homens e mulheres foram citadas: os homens têm mais facilidade para lidar com as ciências exatas, com trabalho mecânico, são mais agressivos no trabalho, como por exemplo, na apresentação de um projeto, fazem isto com mais firmeza e assertividade. São mais diretos e objetivos. Reconhecem que eles têm mais facilidade que as mulheres para conseguirem um estágio ou um trabalho, assim como são mais facilmente aceitos no ambiente profissional. Quanto à remuneração, também os homens levam vantagem, pois, segundo eles, em suas áreas de atuação as mulheres sempre ganham menos que os homens para realizar 0 mesmo trabalho.

Por outro lado, as mulheres são mais organizadas "nunca tem homem no financeiro, porque ele é desorganizado. Isso não é estereótipo, é uma tendência”. Para eles, as mulheres têm mais facilidade e mais tato para lidar com o público e trabalham melhor com decoração.

Quanto a este aspecto o preconceito aflorou, pois o trabalho com decoração foi apontado por vários rapazes como um trabalho feminino e o homem que o faz é confundido com homossexual. "Praticamente decoração associa estilismo com viado (homossexual). Decoração com viado. Um homem prefere evitar". A grande maioria citou o fato de que o homem que trabalha com design sofre preconceitos em virtude de apresentarem "uma sexualidade duvidosa...”.

As mulheres são vistas pelos rapazes em sua maioria como emotivas, sentimentais, sensíveis, delicadas, cuidadosas, mais subjetivas do que os homens. A falta de força física também foi citada como uma característica 
feminina e, para alguns, "é comprovado cientificamente que as mulheres falam mais do que os homens" Além de faladeiras, os rapazes consideram também as mulheres mais fofoqueiras, desleais entre elas e mais desunidas do que os homens.

Estas características acarretam algumas conseqüências nas relações de trabalho que podem, por um lado, favorecer o desempenho das mulheres em algumas atividades e, por outro, prejudicar. Por exemplo, a sua sensibilidade e delicadeza são importantes no trabalho com o público, onde elas são mais eficientes. Disseram que esta capacidade de relacionamento faz com que as mulheres consigam galgar posições, ter mais carisma, "ser uma pessoa mais bem vista dentro de uma empresa". Para outros, "no setor de criação, de concepção de arte, de design a mulher leva teoricamente uma certa vantagem até por questões psicológicas,... é tão da mulher ser lapidada pra ser mais aprazível... ela tem mais percepção pra coisinhas que estão acontecendo no trabalho... ela pode tomar isso como um novo ramo, um novo caminho para criação...”.

Outras qualidades apontadas como femininas e que favorecem o desempenho das mulheres no trabalho foram a organização e uma maior atenção a detalhes e a cores. São eficientes em trabalhos como controle de qualidade, de acabamento, por exemplo, e também no setor financeiro. Elas têm também mais facilidade para trabalhar em redação e mídia.

Segundo eles, as mulheres estão hoje conquistando muitos espaços no mercado de trabalho, mas esta conquista ainda é muito mais difícil para elas do que para os homens, "ela briga duas vezes pra chegar e se impor. A imposição do homem é muito mais simples”. Há uma consciência entre os rapazes de que a sociedade está passando por um processo de transição, saindo de uma situação em que as mulheres viviam em situações de submissão, em que os homens tinham muitos direitos que não eram estendidos a elas. Esta influência histórica ainda está presente, “o sentimento ainda está embutido na sociedade... tanto dos homens quanto das mulheres... existe muita mulher machista...".

Com relação à conquista de novos espaços, um entrevistado afirmou que com a revolução industrial resolveram inundar o mercado (de trabalho) com mulher, questão de mão-de-obra barata...”. Segundo ele, muitas 
mulheres querem trabalhar e não percebem que recebem rendimento menor do que os homens pelo mesmo cargo.

A insegurança profissional foi também apontada pelos rapazes como uma característica feminina que dificulta sua afirmação na vida profissional. Trouxeram exemplos de colegas de curso que não se impõem na defesa de seus projetos e opiniões, não defendem suas idéias com a mesma firmeza e agressividade que os colegas rapazes e não ousam criar nada além do que os professores orientam “... tudo quadradinho, bonitinho, bem resolvido, mas é aquilo. Não vai ter diferença... são mais tranqüilas, mais serenas... é um trabalho assim, assim,... sem muita gana”. Dentre todas as suas colegas, apenas uma delas foi apontada como diferente das outras. Ela discutia com os professores, defendia suas idéias e tinha um trabalho diferenciado, inclusive dos rapazes. Eles explicaram esta diferença pelo fato de ser uma aluna que já possuía um curso de Belas-Artes e tinha muito mais experiência do que suas outras companheiras. Os rapazes apontaram suas colegas de curso como mais disciplinadas e estudiosas do que eles "são bem mais dedicadas,... são mais cdf (muito estudiosas), se preocupam com mais antecedência com os trabalhos... a gente faz mais em cima da hora...”. Nota-se uma certa ironia em comentários como este: “...- eu acho que à tarde (período com maior freqüência feminina) tem trabalhos bem bons... - Apesar de serem meninas?" (risadas).

Uma limitação das mulheres de acordo com a percepção masculina foi com relação a conhecimentos técnicos "grande parte das mulheres não gostam de coisas muito minuciosas que têm muitos comandos... mulher vai achar que motor tem válvula de televisão”. Eles disseram que elas lidam com equipamentos técnicos, porém se ocorrer algum problema técnico não tentam resolver e geralmente recorrem a seus colegas masculinos para pedir ajuda. Segundo eles, é muito difícil encontrar uma mulher que tome a iniciativa de solucionar sozinha este tipo de problema.

A questão familiar foi bastante discutida entre os rapazes e o papel da mulher no mercado de trabalho foi diretamente vinculado a esta questão. Usaram suas experiências pessoais para exemplificar como a percebem. A mãe de um deles, por exemplo, deixou sua atividade profissional para ficar em casa cuidando dos filhos, e ele avalia isto positivamente, pois eles 
tiveram sempre a presença constante da mãe na infância. Outro discordou, citando seu caso "minha mãe sempre foi professora universitária... ela sempre trabalhou muito. Até eu acho que ela nunca deixou de ser mãe. Ela sempre foi muito presente na família... minha mãe fez bem em continuar trabalhando". Para ele, há muitas mulheres frustradas porque pararam de trabalhar fora e quando os filhos já estão criados sentem-se anuladas "muitas mães não são felizes... -Ah, parei de trabalhar... de estudar... e não sou mais ninguém agora...". Outro disse que a mãe só trabalhava meio período, que a mãe teve tempo para cuidar dele. "E é o que eu gostaria de fazer pelos meus filhos... não uma mãe muito ausente...”.

Apesar destas opiniões contrárias quanto ao papel da mulher junto à família e ao mercado de trabalho, houve um comentário de que a mulher tem a opção entre ficar em casa cuidando dos filhos pequenos ou dedicarse à atividade profissional, enquanto o homem é obrigado a trabalhar para sustentar a família.

c) Representações das alunas sobre as relações de gênero no curso e na profissão.

A leitura das entrevistas com as alunas revela que na Instituição, os Cursos de Tecnologia em Artes Gráficas e de Tecnologia em Desenho de Móveis são percebidos como femininos. Elas também entendem que os cursos de engenharia, principalmente mecânica, são considerados masculinos, havendo neles preconceitos contra mulheres. Aliás, acreditam mesmo que a UTFPR possui um perfil masculino.

No entanto não deixam de reconhecer que um olhar mais atento sobre seus cursos não daria margem à caracterização dos mesmos como femininos. Afirmam que existe uma maior interação entre os gêneros entre seus colegas, advinda do maior nível de informação dos alunos, “(...) eu acho que na área que a gente trabalha, com projeto gráfico envolve muita propaganda, marketing, esse tipo de coisa, as pessoas têm um pouco mais de cultura".

De qualquer forma, percebem que o número de alunos é menor principalmente no Curso de Tecnologia em Desenho de Móveis, no qual é possível encontrar turmas nas quais eles estão ausentes. Aliás, associam 
a pouca presença de alunos na área com a idéia tradicional de que o uso da criatividade e da sensibilidade - pré-requisitos para os cursos - seriam características atribuídas a homossexuais. Afirmam mesmo que é difícil um homem suportar o convívio com muitas mulheres, bem como o preconceito que coloca dúvidas quanto a sua masculinidade: “... quando tem um cara, geralmente todo mundo tira sarro, porque falam que é gay”.

Pela leitura das entrevistas é perceptível que os objetivos do curso não estão claros para as alunas:“... mas eu não sabia o que eu ia aprender...". Nas falas, as mulheres se reconhecem competitivas entre si, o que é percebido como um problema “... era muita menina falando, era muita briga na sala, justamente por uma falar demais, uma falava da outra, queriam entrar numa disputa...”. O mesmo não seria válido para os homens, tidos como mais associativos. Elas reconhecem a competição entre homens e mulheres no ambiente estudantil, o que pode ser evidenciado nos ambientes de marcenaria onde a diferença de gênero é reforçada pela faixa etária e pela condição de estudante. "Dificuldade entre homem e mulher só mesmo na marcenaria mesmo, que a gente tem mais ... assim, às vezes os senhores lá que cuidam da marcenaria se irritam com a gente, acham que a gente não tem capacidade de fazer nada, e daí é complicadinho, só isso".

Ainda com relação à marcenaria, pode-se perceber que a mesma se constitui no ambiente em que elas desempenham as tarefas que exigem maior esforço físico, sendo que algumas temem ser enquadradas no estereótipo da homossexualidade. "Eu, às vezes tenho até medo, porque eu já sou grandona, tenho ombros largos, aí de repente, ficá carregando móvel pra cima e pra baixo, falam assim: nossa aquela ali é..., sei lá, meio homem ...”.

As entrevistadas relatam que se sentem alvo de preconceitos neste ambiente de marcenaria até mesmo por parte dos professores, sendo que ocasionalmente ouvem comentários que colocam em dúvida sua capacidade de desempenhar com sucesso as atividades pertinentes a este ambiente.

As mulheres reconhecem que existe uma certa diferença naquilo que produzem, se postas em contraste com a produção masculina, no que se refere aos trabalhos e tarefas desenvolvidos no curso. Isso se evidencia 
quando elas fazem referência a solução de problemas: “... a gente teve que fazer um encarte de cd, e daí um amigo nosso, da sala, fez uma caixinha, simples, bem básica, ele colocou uma fita magnética, tipo um imã, e colou, assim, era um negócio simplíssimo, bem fácil de fazer, enquanto que a gente fez encarte, fez bastante coisa, ... a idéia dele..., não deixou de ter um embasamento teórico, e foi uma idéia simples e uma idéia boa ... não ficou incompleto".

Nos estágios envolvendo vendas de projetos, desconfia-se que a mulher não domine todo o conhecimento que a área exige, bem como, que as relações interpessoais nem sempre se estabelecem em termos profissionais, podendo até transformar-se em assédio sexual ou "cantada”: “... mas quando chegam homens, geralmente eles não levam muito pelo lado profissional, sempre tem aquela coisa de... né, de cair outro lado da cantada...".

Foram citadas de forma recorrente, situações em que no momento da seleção para os estágios, as mulheres são eliminadas antes de seus colegas da disputa devido ao argumento da falta de força física, muito embora esta característica não fosse essencial para o desempenho da tarefa almejada. Em outras situações o mesmo acontece sem motivo aparente ou relevante: "Muitas vezes a gente leva o curriculum para tratar de estágio e eles não te chamam e você não sabe porque, você chega de manhã, fica pensando se está faltando alguma coisa ou se é porque você é mulher, e a gente nem sabe porque na verdade a gente é eliminada primeiro". Vale ressaltar, também, algumas situações de estágio, onde se percebe um preconceito contra os estudantes em geral, sejam homens ou mulheres.

Percebe-se que existe uma distância entre as tarefas desempenhadas por elas nos estágios e os conteúdos e disciplinas desenvolvidos nos cursos: "Eu gostaria de trabalhar em marcenaria, não gostaria de atender público, de cozinha, em vendas, trabalhei com isso e não gostei ... pode ser até uma execução, assim, materiais, fazendo modelos, mas atendendo em lojas eu não gostaria não".

No que se refere ao mercado de trabalho, as falas femininas apontam para uma interação não-conflituosa entre homens e mulheres na área de 
artes gráficas e desenho de móveis, não existindo problemas de diferenças de gênero no que se refere ao desempenho profissional: “... é que o nosso mercado é um mercado bem misto. A gente tem tanto bons designers homens como mulheres ...”. Aliás, afirmam mesmo que para o equilíbrio dos grupos de trabalho e estudo, é necessária a presença de mulheres e homens. Isto porque em um ambiente de trabalho misto é possível ter uma maior empatia quanto às aspirações e exigências das mulheres quando quem faz o projeto é uma mulher; assim como, se o projetista for um homem, terá melhores condições de conhecer mais profundamente as necessidades masculinas. “... Homens e mulheres trabalham juntos em cima do mesmo projeto... Cada trabalho tem que ter um toque de homem e um toque feminino se vai direcionado para homens e mulheres". Entretanto, aparecem nas entrevistas situações que contradizem o que foi aqui exposto, pois as alunas comentaram que os nomes de maior destaque na sua área de trabalho são masculinos.

Em ambientes em que a presença de homens é predominante, as mulheres sentem-ser muitas vezes inferiorizadas. Atribuem esta situação não apenas ao círculo de amizades masculino, mas também a uma maior liberdade existente entre os mesmos. Reconhecem ainda que os homens também sentem dificuldades em ambientes mais femininos, devido aos mais diversos problemas de interação. "O próprio homem também se sentiria mal entrando num espaço onde só tem mulher trabalhando, ele ia querer mostrar alguma coisa, o trabalho, já puxa pra um lado não tão sensível, a mulher é sempre mais sensível, (risos), tudo é mais detalhado, ele também acaba se sentindo um pouco mal, ele entra num espaço, ...ele se sente invadindo um espaço que não é dele...”.

De qualquer forma, admitem a possibilidade das mulheres com 0 tempo alcançarem reconhecimento nos ambientes masculinos. A conquista do espaço se daria, segundo elas, pela demonstração de sua competência ou pelo uso da diferença como estratégia de aproximação, onde as características femininas cativariam a afetividade masculina “... eles vão conhecendo, vão vendo como é o teu trabalho, aí começam a respeitar você, não só como profissional, mas também como pessoa, daí você conquistou o teu espaço, entendeu?”. 
Existe no mercado a presença dos micreiros ${ }^{17}$ que, sem ter formação específica na área, aumentam a disputa por postos de trabalho. Segundo as entrevistas, tais micreiros seriam homens em sua maioria, já que os mesmos teriam um maior interesse pela área de informática, conhecimento necessário para o exercício da profissão.

As entrevistas revelam a idéia de que as mulheres são observadas com desconfiança no que se refere ao domínio dos conteúdos específicos de sua área de atuação. No entanto, as mesmas afirmam que no caso masculino isto não acontece - aliás, eles transmitiriam uma maior segurança e domínio na execução de tarefas que envolvem conhecimentos ligados a computadores, programação, etc. Elas acreditam que este é um dos elementos que contribui para as diferenças de remuneração entre homens e mulheres: "O menino é o que mais ganhava, talvez por ele saber mexer com o programa... acho que pelo fato do domínio desta ferramenta...".

As mulheres afirmam que existem setores em que sua presença pode ser notada com maior freqüência. Poder-se-ia exemplificar no Curso de Tecnologia em Artes Gráficas o desenvolvimento de projetos, e no Curso de Tecnologia em Desenho de Móveis, o setor de as vendas. Embora possam ser encontradas falas que indiquem a preferência pela área de produção, apontam que, nas tarefas ligadas ao chão de fábrica, a sua presença quase não pode ser notada, uma vez que estariam mais reservadas aos homens: “...Geralmente, na parte de fazer força, na parte da execução mesmo, em termos de estágio ou emprego eles escolhem homens...”.

Isto fica evidente em algumas situações que aparecem nas falas das entrevistadas, por exemplo, as características físicas femininas, tais como a falta de força física sendo utilizada contra as mesmas “... Mas na entrevista mesmo (para obtenção do estágio), a pessoa, a coordenadora, me disse que ela estaria dando a preferência pro homem porque ele poderia fazer mais força do que eu para carregar essas caixas, ... e ele não tinha a mesma formação que eu, ele não teria o mesmo conhecimento que eu e a vaga foi preenchida só porque ele poderia fazer mais força do que eu ...”.

17 Micreiros, segundo os entrevistados, são pessoas que exercem a profissão para a qual eles estão se preparando, mas que não possuem o diploma dos cursos de formação profissional da área. 
Elas concordam com o estereótipo de que os homens que mais se destacam na área, são homossexuais: “... Eu vejo que ele é o homem que mais se destaca, eu não sei se é por ele trabalhar há um tempão ou pela influência ... por sinal ele é homossexual, não sei se eles têm uma maior sensibilidade pela própria profissão ...”. Afirmam ainda, que a área é evitada pelo sexo masculino por ser considerada feminina.

Todas as situações acima são retiradas das falas das mulheres, sem que as mesmas as reconheçam como preconceito. Com exceção da afirmação inicial, que nega a existência do preconceito (recorrente nas entrevistas), há apenas uma outra referência ao tema, dizendo que a discriminação em relação às mulheres está desaparecendo.

d) Representações dos alunos sobre as relações de gênero no curso e na profissão.

A análise das entrevistas masculinas revela, numa primeira aproximação, para a não-existência de diferenças relacionadas ao gênero ou ao sexo. No entanto, as falas apresentam seus cursos como femininos. Isto porque envolvem criatividade, uma certa sensibilidade, uso de dons artísticos e pelo fato da área do design ser considerada mais leve, quando comparada, por exemplo, às engenharias. Assim, muitas vezes, a mesma é evitada por uma parcela do público masculino - principalmente no caso do Curso de Tecnologia em Desenho de Móveis, no qual quase não há homens. A pesquisa revelou que os rapazes que iniciam os cursos são questionados com relação a sua masculinidade. "Eu enganei minha mãe pra vir pra cá. Ah, eu ia fazer um curso de homem que é engenharia civil. Daí eu falei que tava fazendo engenharia civil,... meio complexo. E depois caí na desgraça! Agora todo mundo aceitou". Talvez como uma tentativa de compensar o estereótipo de homossexualidade ligado ao curso, apareceram nas falas, de forma recorrente, afirmações de que esta área rompe com padrões estabelecidos, questiona modelos tradicionais, sendo, portanto, um curso moderno. Outros disseram em tom de brincadeira que a entrada dos homens nesta área pode estar relacionada à presença maciça de mulheres. 
É possível notar nas entrevistas a idéia de que o melhor desempenho masculino não está associado a esforço ou dedicação - eles reconhecem inclusive que as mulheres estão mais preocupadas com estas questões do que eles. Entretanto, referem-se a uma maior e melhor qualidade em seus trabalhos, quando comparados com os delas. Isto estaria ligado à idéia de que os mesmos são mais questionadores, sendo capazes de discutir teorias e conceitos com os professores, enquanto as mulheres se submetem às regras sem maiores questionamentos. Inclusive afirmam que elas são mais inseguras com relação aos seus trabalhos, reagindo de forma diferenciada aos sucessos e fracassos da vida acadêmica: "Uma vez na sala de aula o professor passou as notas e uma menina que começou a chorar porque tirou a média 7,5 , pô...”.

Há também a afirmação de diferenças marcadas pelo gênero na produção do design: o dos homens mais arrojados, porém simples, enquanto o delas seria mais estilizado e com mais detalhes: “... o design do homem é mais agressivo do que o da mulher. Ela tem tendências... mais feminilidade no design. O design do homem seria mais grosso, por assim dizer. Um design mais tosco...”.

Com relação aos estágios, nota-se que as falas masculinas parecem encarar as atividades referentes ao mesmo como pertencentes ao mercado de trabalho - já que são acadêmicos e não teriam experiência profissional na área. Isto poderia explicar um certo silêncio sobre o tema: há uma única citação na qual se diz que não existe distinção entre homens e mulheres no momento da seleção dos estudantes.

Pode-se afirmar que os entrevistados não dão maior importância para as questões relativas ao gênero. Acreditam que as mesmas não têm relevância na área: "Então fica difícil você sentar num grupo assim e começar falar sobre essa relação por que é algo que, pelo menos eu ... não me preocupo ...É que na nossa área ...é ruim essa distinção. Eu pelo menos não percebi a distinção ..."

Numa primeira aproximação das entrevistas masculinas, é possível notar falas que apontam para uma igualdade de gênero também sob o âmbito do mercado de trabalho."... A mulher é plenamente capaz de fazer o que o homem faz”. As falas deixam em aberto, pelo menos em 
tese, a possibilidade de mudanças nos papéis sociais tradicionais que apresentam o espaço público como masculino e o privado como feminino, embora tais afirmações tenham como base estereótipos de gênero que demonstram questionamentos e possibilidades de aproximação nos papéis desempenhados por homens e mulheres “... antes o homem era isso e a mulher aquilo. Agora o homem pode fazer o trabalho da mulher e a mulher pode fazer o trabalho do homem. Essa é a aproximação". Consideram o machismo um dado cultural, que será superado no decorrer de algumas gerações.

Com relação ao mercado de trabalho, as falas apontam para uma preocupação com relação à entrada da mulher no mercado de trabalho e à competição com as mulheres. Afirmam mesmo estar sendo preteridos por "mulheres cartão de visitas", e ainda consideram a força física como um fator determinante na definição das tarefas "Comprovadamente a mulher é fisicamente mais fraca do que o homem". Talvez por isso afirmem que existe incompatibilidade entre as mulheres e as tarefas relativas ao chão de fábrica (para eles, a industria é considerada machista). No entanto, contraditoriamente, reconhecem que em alguns ambientes considerados insalubres, pode ser percebida a presença feminina: "E é estranho você ver assim aquela menina toda produzidinha, e tal, daí ela entra no vestiário, sai de macacão, botando a biqueira de ferro, toca na cabeça e vai lá operar a injetora a quarenta e poucos graus, o dia inteiro, aquele barulho, de pé”.

Além do exposto acima, pode-se perceber nas falas um outro fator limitante para a atuação feminina no mercado de trabalho. Trata-se da idéia de que mulheres não interagem bem com aparelhos e artefatos tecnológicos. "Quem que vai lá abrir a máquina, mexer nas placas pra ver como é que tá, os contatos da placa, desmontar e montar de novo. É difícil as mulheres que fazem isso. Eu particularmente nunca vi nenhuma”. Apontam, no entanto, que existem exceções. Assim, segundo eles, na área de artes gráficas, restaria às mulheres o trabalho com redação e atendimento ao público. Mas esta afirmação também não é consensual.

Por outro lado, acreditam que o homem, pelo menos neste campo de atuação, tem que ter uma interação positiva com a tecnologia, creditando o sucesso na profissão à busca e ao domínio de novos conhecimentos. Isto 
porque consideram moderno e inovador este ramo do mercado não estando, portanto ligado a padrões tradicionais estabelecidos. Como consideram que todas estas características são masculinas, é recorrente a idéia de que os homens têm um melhor desempenho profissional do que as mulheres. Assim como as alunas entrevistas, também os alunos disseram que os homens são os profissionais que mais se destacam.

Existem ainda falas que apontam para o fato de que os homens nem sempre se sujeitam a certas exigências impostas pelo mercado: "Daí vamos fazer o seguinte, pega essa cor, muda pra amarelo, o fundo pega roxo, pega essa fonte, coloca essa fonte gótica, e daí coloca esse ursinho de pelúcia aqui atrás e coloca branco com uma letra branca em cima. Daí você pô!? ...' - Não, tô pagando!' E daí você fala o seguinte:' - eu faço, mas se alguém perguntar com quem você fez, fala que não foi comigo. Fala que foi você que fez. Eu não vou assumir a responsabilidade sobre esse produto"”.

Há, nas falas masculinas, uma oposição entre duas idéias: a de que na seleção de candidatos, os homens seriam mais objetivos, levando em consideração a capacidade: "O homem já olha mais a parte profissional. A mulher já vê que o cara é bonitão e vamo dá preferência prá esse cara e tal ...”. e as mulheres são mais subjetivas, deixando-se levar pela beleza. Mas foi afirmado também o oposto: "Ah eu acho que é o contrário, cara. Normalmente o homem olha primeiro a aparência, depois o conteúdo ...”.

Afirmam também a existência de posturas e comportamentos diferentes para ambientes masculinos, ambientes femininos e ambientes mistos, cada um com características específicas. Existe nas falas a idéia de que a presença feminina suaviza o ambiente de trabalho: "Mas eu acho que a relação muda sim. Quando é um ambiente só feminino ou um ambiente só masculino e quando é um ambiente que mistura a coisa, eu acho que muda o comportamento, tanto das mulheres como dos homens, eu acho que a coisa fica mais equilibrada”. Segundo os alunos entrevistados, o ambiente em que há mulheres trabalhando caracteriza-se por um maior respeito entre as pessoas, não há muita briga nem discussão. Por outro lado, há muita intriga.

Entretanto alguns entrevistados disseram que o ambiente de trabalho em que há muitas mulheres é mais tenso porque elas não conseguem separar questões profissionais de questões pessoais; "a mulher leva tudo 
pro lado sentimental, qualquer coisinha, se você falar atravessado, ela vai pro banheiro chorar, vai pro canto, tem enxaqueca..." De acordo com as opiniões deles, "para os homens essas questões são resolvidas de forma mais simples: ficam putos, vão pra um bar, tomam uma cerveja e no dia seguinte está tudo bem". Apontam que homens e mulheres possuem diferentes formas de reagir ao stress no ambiente de trabalho, marcadas pelo gênero: as mulheres exprimindo através do choro, os homens através do lúdico. Falam ainda da necessidade da criação de equipes mistas de trabalho, que atenderiam a todas as necessidades dos clientes.

Assim como nas entrevistas femininas, a idéia de que não existe preconceito de gênero é recorrente nas falas masculinas: "Homem, mulher não tem muita distinção". Entretanto, pôde-se constatar situações nas quais o preconceito é evidente.

É perceptível uma preocupação com relação à homossexualidade, já que nessa área de atuação são exigidas características tidas como femininas, tais como, sensibilidade, criatividade, "mentalidade aberta", dentre outras. Porém, em algumas entrevistas aparece a afirmação de que, em determinados ambientes de trabalho masculino, não haveria condições de convivência com um homossexual, devido à discriminação que sofreria. Percebe-se que a profissão de designer (e também arquitetura), sofre uma preconceito com relação à homossexualidade: "Inclusive, dizem que o designer não foi viado suficiente pra fazer arquitetura e nem homem suficiente pra fazer engenharia". Haveria como exceção o web-designer que, por trabalhar com computadores, não sofreria tal preconceito. De qualquer forma, existe a visão de que a presença de homens em ambientes predominantemente femininos ou mulheres em ambientes predominantemente masculinos se caracterizaria como sintoma de homossexualidade das pessoas do gênero minoritário.

Em oposição ao ambiente machista da indústria, a área de criação é tida como feminina. Nas falas reconhecem a existência de diferenças de cargos e salários entre homens e mulheres: "Já é bem menor, mas eu acho que ainda existe esta diferenciação, as mulheres acabam recebendo um pouco menos e os cargos de chefia ainda em sua maioria são ocupados por 
homens". A presença das mulheres no mercado de trabalho é considerada um fator de acirramento da concorrência: "O meu pensamento é mais machista, acho que a mulher não deveria sair de casa. E com isso a gente ia ter um mercado de trabalho mais limpo".

Ainda com relação às mulheres, afirmam que o mercado não valoriza quem tem mais mérito, pois se existe uma vaga para um emprego que solicita uma mulher e um homem se apresentar com as características exigidas poderá ser contratado, sendo que o mesmo nem sempre aconteceria com uma mulher: “... se há uma oferta de emprego... determinadas características, determinados requisitos para uma mulher e você como homem vai lá e apresenta com essas características, com certeza eles vão te contratar. Agora, se ... com tais requisitos estão pedindo um homem e vai uma mulher, mesmo ela preenchendo todas as características, muitas vezes ela não vai ser contratada, ... por ser uma mulher".

Para finalizar, é necessário frisar que, assim como no caso das mulheres, todas essas situações não são percebidas como preconceituosas, sendo que existe a afirmação de que na área não há preconceitos, que o importante é o currículo pessoal. Afirmam também a necessidade do respeito às diferenças.

\section{INTERPRETAÇÃO DOS RESULTADOS DAS ENTREVISTAS}

Como já apontado anteriormente, a escolha dos cursos de Tecnologia em Artes Gráficas e de Tecnologia em Desenho de Móveis para a realização desta pesquisa deu-se porque um dos interesses em fazer esta investigação era saber se as relações de gênero estão se modificando e de que forma. Cursos desta natureza supostamente teriam alunos mais progressistas, portanto mais abertos a mudanças e com manifestações de preconceitos de gênero menos arraigadas, do que alunos de outros cursos da área tecnológica como as engenharias, por exemplo, nos quais supostamente estudam alunos mais conservadores. Isto porque 0 simples fato dos rapazes terem escolhido este tipo de curso revela sua disposição de romper com padrões tradicionais, tendo em vista que são cursos considerados mais apropriados para mulheres, de um ponto de 
vista conservador, uma vez que exige uma sensibilidade artística, muitas vezes relacionada ao estereótipo feminino, o que não significa que nestes cursos não sejam necessários conhecimentos técnicos, motivo pela qual estão inseridos na área tecnológica.

A partir dos conteúdos das entrevistas acima sistematizados, é possível interpretar como os estudantes e as estudantes percebem as relações de gênero entre eles e elas, no próprio curso e no mercado de trabalho ${ }^{18}$.

Um fato que chamou a atenção da equipe de pesquisadores desde a primeira entrevista realizada foi a afirmação categórica de todas as alunas e alunos de que eles não percebem nenhuma discriminação nem preconceito de gênero no curso que freqüentam. A princípio, para eles, todos os alunos e alunas são tratados da mesma maneira e têm as mesmas chances no curso e no trabalho. Entretanto no decorrer das entrevistas as diferenças afloram.

Os rapazes acham que as moças não têm as mesmas oportunidades de emprego do que eles, dizem que elas recebem menor remuneração pelo mesmo trabalho, que no curso não são tão assertivas e seguras quanto eles para defenderem suas idéias, são muito emotivas e não conseguem superar dificuldades e pressões nas aulas e no trabalho, pondo-se a chorar com facilidade, o que thes tira o caráter profissional e as prejudica. Enfim, apontaram uma série de situações em que as diferenças de gênero significam desigualdades que desfavorecem as mulheres e favorecem os homens, e que colocam a competência profissional em segundo plano.

Da mesma forma, as moças também denunciaram diversas situações em que são prejudicadas pelo fato de serem mulheres. Muitas das justificativas para a preferência pelo trabalho masculino foram dadas pela falta da força física feminina. Elas mesmas reconhecem isto. Porém, nas entrevistas também ficou evidenciado que muitas fazem trabalhos pesados, como algumas tarefas de gráfica e de marcenaria. Além disso, a tecnologia moderna vem criando muitos trabalhos em que é desnecessária a força

18 É importante ressaltar que a interpretação apresentada aqui não esgota toda a riqueza que os dados obtidos nas entrevistas trazem, possibilitando, portanto posteriores análises a partir de seus resultados. 
física. Portanto, esta é uma falsa justificativa que, porém não é assim percebida pelos rapazes nem pelas moças.

Uma outra diferença que tem relação com as questões de gênero é o fato das mulheres, principalmente as mais "bonitas ${ }^{19}$ ", serem utilizadas pelos profissionais da área para serem colocadas nos stands de exposições como vitrines para atrair clientes. Outras são empregadas em lojas de móveis para trabalharem nos projetos de cozinha ou simplesmente para vender as cozinhas, com um salário que não corresponde à sua formação $0^{20}$.

Muitos depoimentos das moças e, também dos rapazes, revelaram que no momento de uma contratação, seja para estágio, seja para um emprego, a preferência é dada para os homens. Isto não acontece sempre, pois em algumas atividades, o trabalho feminino é preferido. Em decoração, atendimento a público, projetos gráficos, por exemplo, as moças foram apontadas como mais aptas devido às características consideradas femininas que as favorecem. Porém, os trabalhos que necessitam destas características são menos valorizados, não só com relação à posição social de quem o executa, mas também financeiramente. $O$ problema que se aponta não está nas diferenças entre as características consideradas masculinas ou femininas, que fazem parte da vida social em todas as sociedades, mas em sua hierarquização, que as coloca em posições desiguais, onde as manifestações femininas são inferiorizadas, o que fica evidenciado pelo salário inferior que as mulheres recebem para a realização do mesmo trabalho feito pelos homens.

$\mathrm{O}$ fato de os informantes terem feito estas revelações e, ao mesmo tempo, não perceberem nenhuma forma de discriminação pode ter vários significados. Por um lado, pode ser que nem eles (e nem elas), percebam estes fatos como manifestações de preconceito ou discriminação. Por outro, pode ser que eles não explicitem a existência do preconceito porque, para este grupo, admiti-lo não seria uma atitude politicamente correta.

19 Usa-se aqui uma expressão extraída diretamente das entrevistas. No entanto é clara a referência aos discutíveis padrões estéticos e estereótipos de beleza veiculados no ocidente: a mulher branca, alta, magra, com um comportamento moral condizente com a sociedade sexista ocidental.

20 Há que se considerar que o contato e a experiência em seu campo profissional, para a maioria dos entrevistados, se restringe às atividades de estágio. 
Afinal, é parte do ideário de alguns estratos das classes médias que estão em sintonia com os avanços da modernidade, acreditar em mudanças nas relações de gênero que se refletem em uma maior independência para as mulheres e uma maior participação dos homens na esfera doméstica, para que as mulheres possam exercer seu trabalho. Considerando as características do grupo entrevistado e de suas famílias, tudo indica que estes estudantes fazem parte de camadas sociais progressistas, mais abertas às mudanças socioculturais do mundo de hoje, mesmo que sendo oriundos/as de grupos tradicionais. Portanto, reconhecer tais preconceitos não estaria de acordo com a visão de mundo deste grupo. Esta pode ser a razão das contradições existentes em suas representações, ainda calcadas em códigos tradicionais para o masculino e o feminino.

Este preconceito irrefletido pode ser interpretado como o fruto da incorporação dos estereótipos tradicionais, o que remete ao conceito de habitus, formulado por Bourdieu, o qual se refere a um produto da sociedade que organiza e estabelece parâmetros para ações concretas. Tal situação é resultado das práticas compartilhadas, que são ambíguas, já que os/as atores/atrizes em questão possuem uma multiplicidade de valores e representações: ao mesmo tempo em que ocupam um universo de estudantes de ensino superior, onde posturas mais tradicionais em relação ao gênero são vistas como ultrapassadas, também possuem representações oriundas de outros espaços de socialização, e que estão permeadas por estereótipos de gênero. Vale lembrar que o mundo universitário não está isento destas representações estereotipadas, como pode ser verificado em várias falas do texto.

Outro ponto importante a ressaltar e que chamou a atenção dos entrevistadores foi a ênfase com que os rapazes falaram sobre o papel de provedor que eles têm internalizado em suas representações, uma evidência a mais da incorporação do estereótipo tradicional. Apesar de alguns explicitarem que hoje em dia este papel está mudando e que, também, as mulheres trabalham para sustentar a família, a maioria deles falou que esta é uma obrigação dos homens. Vários deles comentaram que estão estudando e irão trabalhar para que possam sustentar suas futuras famílias. Foi inclusive citado como o grande 
sonho de suas vidas: poder suprir sozinhos para a família todas a suas necessidades materiais.

Por outro lado, esta foi uma preocupação que não surgiu em nenhuma fala das entrevistadas. Nenhuma moça evidenciou preocupação em estudar e se formar para ter um emprego e poder sustentar a família. É claro que elas estão estudando para ter uma profissão e para poderem trabalhar, porém em nenhum momento falaram que precisavam trabalhar para ganhar dinheiro, muito menos que precisavam garantir economicamente seu futuro ou o de suas futuras famílias. Aliás, nem mesmo o tema casamento estava presente em seus discursos, assim como não estava entre suas preocupações ter que "ganhar a vida". Nas falas dos rapazes, por sua vez, tais temas como subsistência, papel do pai, papel da mãe, preocupações com o futuro, entre outras, estiveram muito presente.

Esta diferença de preocupação pode ser interpretada pelo fato dos rapazes terem internalizado fortemente o papel de provedor em suas vidas. Apesar das mudanças no papel da mulher na sociedade de hoje, assim como seu ingresso indiscutível no mercado de trabalho e as transformações nos papéis de gênero, tudo indica que os homens entrevistados introjetaram de uma maneira marcante o padrão do homem como provedor da família. Não se pode negar que há ambigüidades em seus discursos quanto a esta questão, porém não se pode negar também que todos eles têm este modelo muito presente em suas representações. Esta preocupação dos rapazes com o papel de provedor é fruto de representações mentais oriundas de práticas sociais nas quais eles ainda não estão inseridos, pois não são ainda provedores de suas famílias e, como estudantes, ainda não estão atuando profissionalmente no mercado de trabalho.

As moças também revelaram algumas ambigüidades com relação ao papel da mulher e as relações de gênero, porém o silêncio da parte delas com relação ao sustento da família revela que esta não é uma preocupação presente em seu universo. Poder-se-ia atribuir este silêncio à maneira pela qual historicamente as mulheres adentraram no mercado de trabalho, ou seja, muito mais como complemento para a renda das classes proletárias do que por um desejo de emancipação feminina. Este fato está presente ainda hoje na representação de muitas mulheres, mesmo quando suas atividades 
profissionais são essenciais para a manutenção de suas famílias. Pode ser interpretado como uma permanência de padrões tradicionais, já que as informantes não relacionaram seu desempenho e sucesso profissional ao papel de provedora da família. Aliás, não surgiu também em suas representações preocupação com o casamento. Nenhuma aluna entrevistada comentou se deseja ou não casar, formar família, como seria sua futura vida familiar, fato que esteve bastante presente nas entrevistas dos rapazes.

As falas masculinas estão calcadas em uma preocupação com a entrada das mulheres no mercado de trabalho, onde a presença feminina representa uma ameaça ao desempenho do papel masculino de provedor da família. Esta ameaça existe, não porque as mulheres poderiam tornar-se provedoras, mas porque com a presença delas, a competição no mercado de trabalho torna-se ainda mais acirrada. Este contexto interfere nas relações de gênero, já que os rapazes buscam em estereótipos tradicionais a demarcação de seus papéis: questionam a entrada das mulheres no mercado de trabalho, porque elas não têm as mesmas responsabilidades que eles. Caso não consigam cumprir o papel de provedor, eles sofrerão cobranças, censura e estigmatização por parte da sociedade.

As falas dos informantes não deixaram de apontar que a família está passando por um processo de transformação e que os modelos tradicionais de gênero já não são mais totalmente reproduzidos. Muitas destas mudanças estão sendo provocadas pelo mercado de trabalho, no qual se percebe a presença cada vez mais efetiva das mulheres e também pela mídia. Questionaram, por outro lado, a quem caberia os cuidados e a educação de seus filhos. Enquanto alguns admitiram que assumiriam este papel, outros sequer mencionaram a possibilidade de participarem no trabalho doméstico e cuidado dos filhos. Estes fatos permitem dizer que há uma ambigüidade constante entre os jovens que oscila, ora para os padrões tradicionais, ora para inovações de gênero.

Faz parte do padrão tradicional de masculinidade que os homens devem estudar em cursos do universo tecnológico que não sejam relacionados a atividades artísticas. As opiniões dos entrevistados sobre os rapazes que estão no curso de Artes Gráficas e Desenho de Móveis revelaram que há um certo preconceito na sociedade em geral a este respeito. Para alguns esta 
maneira de pensar criou problemas até para ingressarem nos cursos. Vimos que um deles chegou a mentir para a mãe que estava fazendo vestibular para o curso de Engenharia Civil e quando foi descoberto o seu verdadeiro curso teve que enfrentar a resistência dos familiares. Outro, disse que o pai sentia-se constrangido perante os amigos pelo fato do filho estar cursando Artes Gráficas e não um curso "de homem”.

Com relação ao curso de móveis, o preconceito é maior porque historicamente na UTFPR este curso originou-se do Curso Técnico de Decoração que era um dos únicos considerados "para mulheres" dentre os cursos técnicos da Instituição. Esta tradição vem criando alguns problemas para as moças porque é visto como um curso feminino que, no entanto, exige força física para o trabalho de marcenaria e, de acordo com os padrões de masculinidade, é mais apropriado para os rapazes. O objetivo do curso é que os alunos sejam preparados para trabalharem nas indústrias de móveis da região, com os marceneiros tradicionais que já possuem a experiência em marcenaria e não aceitam a participação das moças recém-formadas que têm a teoria, porém não têm a prática. Elas têm enfrentado dificuldades junto a este tipo de profissional, não somente por serem mulheres, mas também por serem jovens e também por estarem em formação, no caso das estagiárias, por exemplo. Conseqüentemente, as atividades em que elas conseguem colocação no mercado de trabalho vêm sendo no comércio, especialmente de cozinhas e são absorvidas também para trabalharem em projetos, atendimento ao público ou para a venda de móveis propriamente dita.

As entrevistas revelaram que há um sentimento de inferioridade entre as mulheres em ambientes considerados masculinos e um mal estar dos rapazes quando estão em um curso considerado feminino. A percepção de que existem espaços masculinos ou femininos demonstra uma construção histórica, que reserva determinados ambientes (como o mercado de trabalho, por exemplo) aos homens. Esta análise remete à idéia de Scott (1995), que apresenta o gênero como uma forma primária de constituir relações de poder. No Ocidente, o espaço público está marcado tradicionalmente como masculino e o privado como feminino. É importante ressaltar que tais padrões não são estáticos, mas estão sujeitos a transformações advindas das práticas individuais, que contribuem para romper com os modelos tradicionais. 


\section{CONSIDERAÇÕES FINAIS}

Sabe-se que a participação das mulheres nos cursos tecnológicos e nas profissões que envolvem a tecnologia é hoje uma realidade. Apesar de ainda serem minoria o número delas no mercado de trabalho tecnológico vem crescendo sistematicamente nos últimos anos. Porém, desigualdades ainda são evidentes quando se percebe, por exemplo, que há uma preferência deste mercado pelo trabalho masculino para atividades mais importantes e melhor remuneradas em detrimento das mulheres que são preferencialmente absorvidas em atividades secundárias, portanto menos valorizadas sob o ponto de vista financeiro. Outra manifestação da desigualdade ocorre em situações em que elas recebem menor remuneração para a execução de um mesmo trabalho feito pelos homens.

Para que estas desigualdades sejam minimizadas é preciso que homense mulheres estejam igualmente preparados/as para atuarem como profissionais em atividades técnicas. No entanto, esta pesquisa revelou que a igualdade de competência não significa necessariamente igualdade de oportunidades no mercado de trabalho tecnológico. As representações sobre relações de gênero das alunas e dos alunos entrevistados mostraram que os rapazes consideramse mais competentes para o trabalho técnico, devido a suas características de personalidade como a objetividade e assertividade, vistas por eles como essenciais para o sucesso profissional na área tecnológica.

Apesar de não se considerarem menos competentes do que os rapazes para executarem trabalhos em sua área de formação profissional, as alunas comentaram que os nomes no mercado de trabalho de maior prestígio e sucesso são masculinos. Segundo elas, isto acontece porque se vive ainda de acordo com um passado histórico que marcou profundamente os papéis dos homens e das mulheres na sociedade e que, apesar de estar em transformação, ainda não modificou totalmente as relações de gênero no mercado de trabalho.

Portanto, as representações sobre as relações de gênero do universo entrevistado oscilam entre manifestações tradicionais, marcadas pela desigualdade e relações de poder e as transformações que estão ocorrendo em direção à igualdade entre homens e mulheres. Este processo de transformação é acompanhado por ambigüidades que permeiam o discurso dos informantes, pois suas opiniões dificilmente são unânimes e raramente sem contradições. 
O próprio processo de socialização faz com que os rapazes sejam preparados para dominarem a esfera pública, na qual se desenvolvem as atividades correspondentes à produção de tecnologias, caracterizada pela objetividade e racionalidade, enquanto as moças são estimuladas a viverem no domínio privado, que se caracteriza pela afetividade e subjetividade. Esta diferença por si só não significa desigualdade, porém quando se trata da sociedade de mercado, em que a produção de riquezas materiais é a mola propulsora de toda a vida social, e o desenvolvimento tecnológico seu valor maior, as relações de gênero, configuradas pela oposição entre 0 domínio público e privado, tornam-se desiguais.

Sem dúvida, está ocorrendo hoje um processo de transformação que foi evidenciado nos resultados da pesquisa realizada. Para melhor compreender esse processo e as possibilidades de alcançar igualdade de oportunidades para homens e mulheres no universo tecnológico é preciso conhecer a lógica e os significados que estão presentes nas atitudes e nas relações dos atores sociais que dele participam. Neste mundo globalizado, em que as relações socioculturais estão ultrapassando as fronteiras nacionais e territoriais, a perspectiva intercultural é especialmente rica para ampliar a compreensão a respeito das relações de gênero na sociedade em geral e no âmbito da produção tecnológica em particular.

A comparação entre os resultados desta pesquisa e os resultados da pesquisa realizada entre as alunas e os alunos dos cursos da área de tecnologia de Furtwangen-Alemanha,- segunda etapa do projeto intercultural - certamente irá contribuir para trazer um maior entendimento sobre as relações de gênero em instituições de educação tecnológica em diferentes culturas, assim como ampliar a compreensão dos fenômenos culturais no processo de globalização.

\section{REFERÊNCIAS}

BOURDIEU, Pierre. A dominação masculina. Rio de Janeiro: Bertrand Brasil, 1999.

BOURDIEU, Pierre. Esboço de uma teoria da prática. In: ORTIZ, Renato (Org.). Pierre Bourdieu. São Paulo: Ática, 1983. p. 46-81. 
COULON, Alain. Etnometodologia. Petrópolis: Vozes, 1995.

GARFINKEL, Harold. Studies in Ethnomethodology. New Jersey: Englewood Cliffs, 1967.

GEERTZ, Clifford. Interpretação das culturas. Rio de Janeiro: Zahar, 1978.

MUNDER, Irmtraud; CARVALHO, Marilia Gomes de. Mujeres y estudios técnicos, ¿conceptos compatibles? Tentativa de una comparación intercultural entre Alemania y Brasil. In: $\mathrm{V}$ CONGRESO IBEROAMERICANO "CIENCIA, TECNOLOGíA Y GÉNERO", 2004, Cidade do México. Cadernos de gênero e tecnologia, n. 2. Curitiba: Ed. CEFET-PR, 2004.

SCOTT, Joan. Gênero: uma categoria útil de análise histórica. In: Educação e Realidade: gênero e educação. Porto Alegre. v. 20, n. 2, $\mathrm{jul} / \mathrm{dez}, 1995$.

WELLER, Wivian. Karl Mannheim e o método documentário de interpretação: uma forma de análise das visões de mundo. In: Estado e Sociedade. Revista do Departamento de Sociologia da UnB. Brasília, 2003.

"A adaptação do método documentário de interpretação de Karl Mannheim para a pesquisa qualitativa". Texto-base redigido para o Workshop Método documentário de interpretação: aspectos teóricos e metodológicos, realizado em Curitiba, no CEFET-PR, nos dias 6 e 7 de maio de 2004 (Mimeo). 
